NBER WORKING PAPER SERIES

MANAGING PUBLIC INVESTMENT FUNDS:

BEST PRACTICES AND NEW CHALLENGES

\author{
Olivia S. Mitchell \\ John Piggott \\ Cagri Kumru \\ Working Paper 14078 \\ http://www.nber.org/papers/w14078 \\ NATIONAL BUREAU OF ECONOMIC RESEARCH \\ 1050 Massachusetts Avenue \\ Cambridge, MA 02138 \\ June 2008
}

Funding for this research was provided by the Economic and Social Research Institute/Cabinet Level/ Government of Japan, the Pension Research Council, and the Australian Research Council. We are grateful to Eric Hou for his research assistance and for comments from Yoshibumi Aso, Junichi Sakamoto, Hideaki Tanaka, and participants at the 2008 ESRI meetings. The views expressed herein are those of the authors and do not necessarily reflect the views of the National Bureau of Economic Research.

NBER working papers are circulated for discussion and comment purposes. They have not been peerreviewed or been subject to the review by the NBER Board of Directors that accompanies official NBER publications.

(C) 2008 by Olivia S. Mitchell, John Piggott, and Cagri Kumru. All rights reserved. Short sections of text, not to exceed two paragraphs, may be quoted without explicit permission provided that full credit, including $\odot$ notice, is given to the source. 
Managing Public Investment Funds: Best Practices and New Challenges

Olivia S. Mitchell, John Piggott, and Cagri Kumru

NBER Working Paper No. 14078

June 2008, Revised August 2008

JEL No. G18,G2,G22,G23,G28,G32,H5,H54,H55

\begin{abstract}
Large publicly-held pools of assets are playing an increasingly prominent role in the global investment arena. We compare three distinct forms of such public funds, namely foreign exchange reserve funds, sovereign wealth funds, and public pension funds, to highlight their differences and similarities. We review previous studies on ways to better secure prudent and economically sound public fund management practices in these funds, as well as how to evaluate their governance and investment policies and how to better protect the assets from political interference. Drawing from the pension and corporate finance literature, we also link their management to governance practices and country-specific characteristics, and contrast those with empirical findings on linkages with corporate governance.
\end{abstract}

Olivia S. Mitchell

Dept of Insurance \& Risk Management University of Pennsylvania, Wharton School 3620 Locust Walk, St 3000 SH-DH

Philadelphia, PA 19104-6302

and NBER

mitchelo@wharton.upenn.edu

John Piggott

School of Economics

University of New South Wales

Sydney 2052, Australia

j.piggott@unsw.edu.au

\section{Cagri Kumru}

Department of Economics

Australian Business School

University of New South Wales

Sydney, Australia 2052

cs.kumru@unsw.edu.au 


\section{Managing Public Investment Funds: Best Practices and New Questions}

Olivia S. Mitchell, John Piggott, and Cagri Kumru

Governments everywhere are amassing large pools of resources held by and managed for the public sector. The media calls these asset pools variously "future funds," "sovereign wealth funds," and "government investment funds," and these entities afford their sponsoring nations both opportunities and risks depending on how these national endowments are managed. As these publicly-held wealth funds grow, they are assuming an increasingly prominent role in news-making international investments, including providing support to some of the world's most important and often-troubled financial institutions (Scheherazade and Blitz 2007). Analysts regularly comment on the size and potential international clout of these financial behemoths (Morgan Stanley Global 2007), and some of the investment choices made by these funds have prompted policymakers including the governments of France and Germany to worry publicly about the potential economic impact of these funds' global reach (Economist 2008). In parallel, international agencies including the OECD and the International Monetary Fund have begun to ask questions publicly about what these funds are and how they should be managed. ${ }^{1}$

Our paper analyzes new information about 'best practice’ management techniques for such publicly-managed investment pools, focusing particularly on governance and reporting patterns along with how one might seek to protect the assets from political interference. We do so to glean lessons on which governance and accountability approaches appear to be well suited in the case of these publicly-held wealth funds, and we also draw out policy inferences regarding governance reform. We show that these publicly-managed investment funds have many different historical roots, including a purposeful buildup of fiscal surplus against future economic shocks (e.g.

\footnotetext{
${ }^{1}$ See also Musalem and Palacios (2004).
} 
Australia, New Zealand); a focused effort to mitigate the effects of demographic disequilibrium on the social security balance (e.g., Japan); or a desire to set aside some portion of revenue associated with the exploitation of natural resources (e.g. Norway). In value terms, the Japanese public pension reserve is among the largest, with some US\$912 billion in accumulated funds (Matsui and Suzuki 2007). Other large funds include that of the United Arab Emirates (US\$875B), Singapore’s GIC fund (\$330B), and Norway’s Pension Fund (US\$300B); see the Economist (2007).

In what follows, we take up several questions of key importance to public investment funds. First, we ask what constitutes “good management practice,” by which we mean the protocols and practices regarding fund governance, accountability, and investment policies (below we outline what we mean by each of these). Second, we ask how good management of public investment funds affects fund performance. In order to do so, it is necessary to evaluate what types of performance metrics exist and whether they might depend on the type of fund. We also review the literature regarding the effect of management practice on performance of public investment funds. Third, we explore whether good management practices for public investment funds for governance, accountability, and investment policies appears to be linked to key aspects of a nation's economic, political, and social conditions. In particular, we evaluate the association between a nation's publicly-run asset pools and its management practices, economic environment, political/legal structure, and practice regarding transparency/ reporting/accountability. We also assess whether the size of future calls on resources, measured here by the aged dependency ratio, influences management practices. As nations become aware of promises made in the form of aged-care benefits, and as financial market upheaval provides these public investment pools with new opportunities and challenges, there will surely be stronger calls for better public fund investment performance. 


\section{The Nature and Variety of Public Investment Pools}

In this paper we refer to public investment funds as those investible assets under the control of the public sector. In practice, these take three main forms: foreign exchange reserve funds held for stabilization purposes; sovereign wealth funds accumulated from natural resource taxes or fiscal surpluses; and public pension funds built up either through an explicit funded arrangement or the result of an excess of contributions over benefits during a demographic transition.

From the perspective of investment discretion, we place currency stabilization funds at one end of the spectrum. These assets must be liquid and are usually held in the form of short term paper or commodities. Moving along the spectrum, sovereign wealth funds (SWFs) are government investment vehicles that manage their assets separately from official foreign exchange reserves. As a rule, their assets tend to be invested internationally, though sometimes they have been used for domestic investments (e.g. infrastructure). Some analysts are quite specific in what they refer to as SWFs: for example, Jen (2007) specifies that the pool must be managed by a government (sovereign entity); it must have high foreign currency exposure; it must have no explicit liabilities; it must have high risk tolerance; and it must have a long investment horizon. In what follows, we take a broader view in encompassing investible publicly managed funds more generally.

A third type of publicly managed money consists of reserves built up for public pension purposes. Due to their long term nature of their liabilities, these funds are typically less constrained by the need for immediate liquidity. Nevertheless, also because of their liability profile, the asset allocations in these funds are often weighted toward domestic currency assets as this is the currency of the pension promises. In particular, public pension funds are often concentrated in government bonds as a result of explicit policy or institutional tradition. For instance, the US Social Security 
Trust Fund of almost US\$2 trillion is held entirely in special-issue nonnegotiable US government bonds.

Of the three types of public investment funds, sovereign wealth funds seem to be growing most rapidly and have been permitted the greatest investment flexibility. Some SWFs were established to manage the intertemporal allocation of resources generated by the discovery and exploitation of a non-renewable natural resource, while others were set up to absorb government fiscal surpluses expected to be spent in the future. One way or another, both pension funds and SWFs have an inter-temporal or even an intergenerational dimension in their objectives. We explore the form and function of each, in what follows.

Currency Stabilization Funds. Though currency stabilization funds are not the central focus of the present paper, it is worth noting that they are the largest of the three categories of public investment funds. Available estimates place the total at around US $\$ 4.5$ trillion (see Table 1). These have been rationalized by perhaps the oldest and most conventional explanation for government-held funds, namely the central monetary authority's desire to smooth currency fluctuations. In practice, it is often stated that three months' of reserves is a prudent cushion for exchange rate shocks (Rietveld and Pringle 2007). In point of fact, many nations hold far more than the minimum level of assets required to manage currency stabilization, giving rise to more aggressive investments via sovereign wealth funds. For example, in China, Russia, and Singapore, SWFs are responsible for both foreign exchange reserves and fiscal surpluses. An important stimulus behind the recent growth in SWFs has been the rising central bank reserves in rapidly growing countries such as South Korea and Taiwan. Official reserves in such funds have expanded at US\$600 billion per year over the past half-decade (Patelis 2007), and reserves held for currency stabilization are expected to rise in the 
future. Nevertheless, as our present concern is with asset pools held for the long run, we do not further consider stabilization pools below.

Table 1 here

Sovereign Wealth Funds. Despite substantial media and policymaker interest in SWFs of late, their precise magnitude is unknown for reasons to be discussed below. One estimate suggests they hold between US\$1.5-\$3.1 trillion (Kern 2007; Patelis 2007). Truman (2007a,b) identifies around two dozen SWFs which he contends control around US\$2 trillion in assets; he also separately lists foreign exchange reserves held by governments totalling about US\$4 trillion and he includes Japan’s approximately US\$800 billion pension fund. Conservative estimates from Watson Wyatt (2006, 2007) suggest that SWFs and public pensions together hold about US\$4 trillion. Figure 1 provides a comparison of assets held by both public and private funds, and it indicates that currency stabilization and pension funds are far larger than SWFs, while SWFs in turn are larger than hedge funds in the global capital market.

Figure 1 here

Many of the early SWFs were set up in countries holding natural resources (e.g. petroleum) which then became exposed to unpredictable revenues due to commodity price volatility. As an example, if a country's oil revenue represented 20 percent of its gross domestic product, then a one standard deviation shock to oil prices would create a revenue decrease equivalent to six percent of GDP (Hausmann and Rigobon, cited in Devlin and Titman 2004). Chile’s Economic and Social Stabilization Fund and the Venezuela Macroeconomic Stabilization Fund are examples of stabilization funds designed to offset such commodity price fluctuations. One way that governments might seek to handle commodity price risk could be to transfer risk to international capital markets so as to smooth economic performance over the relatively short term (Arrau and Claessens 1992). 
But the thinness of international insurance markets and apparent borrowing constraints are believed to make self-insurance a more natural choice for oil-producers to protect themselves against such price volatility. Indeed, self-insurance is recommended by Shabsigh and Ilahi (2007) who contend that the benefits from public expenditures on lumpy investments when oil prices are high exceed the costs of shutting them down when oil prices are low. Commodity-exporting countries may selfinsure against volatile commodity prices either by diversifying their export structure or accumulating financial assets. Since diversifying export structure requires long-term structural reform and may reduce comparative advantage, financial asset accumulation can be a better choice given available alternatives. ${ }^{2}$

There is some controversy about the economic rationale for such stabilization funds. For instance Davis et al. (2001) find that fiscal stabilization funds may be less efficient than sound fiscal policy in protecting against commodity price volatility. On the other hand, Shabsigh and Ilahi (2007) analyze the effects of stabilization funds not only in terms of fiscal but also in terms of macroeconomic stability. The latter study concludes that inflation and price volatility prove to be lower when countries keep stabilization funds, and it weakly supports the proposition that commodity funds could be useful macroeconomic stabilizers. On the whole, the economics literature suggests that commodity funds will be small when motivated by commodity price fluctuations, since larger funds distort the domestic economy and can trigger suspicions about the fund's activities in international financial markets (Devlin and Titman 2004).

A separate justification for SWFs is that they permit nations to set aside money for future generations derived from exploiting exhaustible resources today. For instance, the first commodity SWF was the oil fund established by the Kuwait Government in 1953; shortly thereafter the nation

\footnotetext{
${ }^{2}$ See Arrau and Claessens (1992), Shabsigh and Ilahi (2007), and Fasono (2000) for a more detailed discussion on the necessity of fiscal stabilization funds.
} 
of Kiribati established a commodity fund in 1956 in order to manage revenues from phosphate deposits (Petelis 2007; Truman 2007b). More recent examples include the state of Alaska which has put 2.5 percent of its oil royalties into its Alaska Fund. This practice is thought to improve intergenerational equity, smoothing the time path of revenues generated by nonrenewable resources (Olters 2007).

A theoretical grounding for this conclusion is offered by Gerlagh and Keyzer (2001) who use a model of a government-run "trust fund" that pays future generations claims for revenues generated by the natural resource. They construct a simple pure exchange overlapping generations (OLG) setup with an exhaustible resource. Exhaustibility is the irreversible degeneration of the resource, while the resource's "amenity value" refers to the services provided by exploiting it. Inasmuch as natural resource extraction today reduces the resource's amenity value tomorrow, a regulatory mechanism is required to promote intergenerational equity. Agents maximize lifetime utility by selecting consumption levels of private and public goods, and aggregate welfare is the summation of individual lifetime utilities. The model considers three alternative regulatory scenarios. In a first, there is zero extraction preventing the use of natural resources for all generations, akin to keeping an oil field idle. The second scenario, termed 'grandfathering,' leaves the ownership of the natural resource to the first generation, while future generations pay to mitigate pollution. This is equivalent to the distribution of all oil or mineral revenues to the first generation. The third scenario introduces a trust fund which entitles all generations to an equal claim over the natural resource. The authors consider the trust fund as an independent institution that can ensure future generations receive their claims; it is like a saving fund to keep some of the revenues generated by an exhaustible resource for future generations. A comparison of the three scenarios in terms of social welfare indicates that grandfathering improves efficiency compared to the zero 
extraction policy, but it favors the first generation over others. By comparison, establishing the trust fund improves welfare for subsequent generations.

An alternative, though related, model of a SWF fund has been termed a financing fund, built up when a government has a budget surplus that it wishes to dedicate to investment instead of current spending. Some argue that this sort of investment pool is more likely to constitute true "saving," as compared to a stabilization fund, because the latter tends to be paid for via borrowing (often implicitly; c.f. Fasono 2000). Of course, such financing funds are often seen as promoting intergenerational equity and fiscal stability; examples include the Norway Government Pension Fund-Global (GPFG), the Kuwait General Reserve Fund, and the Timor-Leste Petroleum Fund. Table 2 provides a listing of the major SWFs and their asset holdings, as well as their stated objectives and sources assembled from a variety of recent sources.

Table 2 here

There is also much interest regarding SWF investments, a topic of particular salience of late as key global financial institutions receive massive inflows from important Asian funds including the Singaporean Government Investment Corporation and the Chinese government investment fund. One reason these transactions have garnered so much public comment is that public investment pools have traditionally not revealed much about their holdings or governance structure. Such nontransparency has been justified on grounds that it preserves investment flexibility and protects business opportunities, but of course this also means that one cannot obtain much useful information regarding the majority of SWF funds' asset allocation patterns. Furthermore, inasmuch as most SWFs do not acknowledge specific liability profiles, they rarely to finance any specific time path of benefits or cashflows denominated in domestic currency. 
How SWF asset managers tend to invest their government-managed pools is difficult to ascertain. Some information for four of the more transparent funds is reported in Table 3. Here we see that Norway's SWF has a 100 percent global portfolio with a roughly 40-60 split between equities and bonds. New Zealand's fund holds about half its assets in international equities; it holds no foreign bonds but has nearly a quarter of its portfolio in "other investments" which may include domestic real estate. Ireland's SWF holds nearly $90 \%$ of its assets in international securities, mostly equities. Australia's very new public investment pool is unique in holding mainly domestic securities but this is changing as procedures are established for global diversification.

Table 3 here

Sovereign Pension Funds. The third category of government-controlled asset pools we scrutinize here consists of the reserves held by government-run public pension funds where, in principle at least, the assets are earmarked for the payment of current and future retiree benefits. These reserves might be generated through an intentionally-funded pension scheme, or they can alternatively be built up as 'transitional' reserves generated by population aging where contributions from a large cohort of workers result in a temporary flow of funds in excess of current benefits payouts. A number of countries have well-funded national pension schemes, and several of them have accumulated substantial assets associated in their future fund accounts. According to Watson Wyatt (2007), public pension funds around the world are 1.7 times as large as the total estimated size of SWFs. Iglesias and Palacios (2000) document most of the publicly-mandated pension funds and the amount of assets held by these funds as a percentage of GDP. Table 4 lists the major sovereign pension funds and their asset holdings.

Table 4 here 
What usually characterizes public pensions is that contributions and payouts tend to be linked through some implicit or explicit contractual arrangement to pay old-age benefits. ${ }^{3}$ In such a circumstance, a public pension fund may build up assets to cover future pension liabilities without necessarily changing the fundamental tax and benefit structure of a pay-as-you-go (PAYG) system. Many economists see a pure PAYG system as welfare-reducing, since it tends to decrease an economy’s capital stock by taxing the young generation with a high propensity to save, so as to pay retiree pensions to those with a high propensity to consume (Kumru and Thanopoulos 2007). By contrast, a funded public pension can invest excess contributions for future generations which can prove useful in the face of demographic aging (Abel 2001). Building up 'future funds' in this context can mitigate the negative welfare effects of a pure PAYG system, though they can also increase intergenerational inequality in a closed economy by benefiting one cohort over another (Lucas, 2001; Oshio 2004; Auerbach and Lee, 2008). In other words, saving excess contributions in a future fund may still be less desirable from a welfare standpoint, to lowering taxes on younger generations.

Recognizing that public pension pools of assets do exist in many nations, it is of interest to examine how such schemes invest their assets. Economists look at this issue in various ways. Some use actuarial or asset liability management (ALM) perspectives to link fund assets and liabilities, while others employ a general equilibrium framework to consider the effects of an investment change on the whole economy. For instance, MaCurdy and Shoven (2001) adopt an actuarial framework to explore the consequences of an asset reallocation from bonds to stocks in the U.S. Social Security Trust Fund. Specifically they examine whether selling government bonds and buying corporate stocks would improve the finances of the mainly PAYGO old-age system. The

\footnotetext{
${ }^{3}$ A further distinction in these funds relates to the form of payout. Defined benefit (DB) plans promise a payout defined in terms of salary achieved; defined contribution (DC) arrangements rely on investment performance of accumulated contributions. See United Nations (2007).
} 
conclude, using historical return data, that such a reallocation would carry significant risk to participants (that is, the relocation might yield lower returns than expected). Using a general equilibrium framework, Abel (2001) analyzes the effects of asset reallocation in Social Security on the equilibrium equity premium and the equilibrium growth rate of the capital stock. He concludes that when a national pension fund moves into equities, the expected income of the trust fund will rise but the welfare consequences are ambiguous. ${ }^{4}$ Similarly, Bohn $(1999 ; 2002)$ shows that welfare effects of the asset reallocation depend largely on the specific pattern of macroeconomic shocks, the risk characteristics of equities, and individual preferences. In general, it is not assured that intergenerational equity results from increasing assets held by the public pension. ${ }^{5}$

Various empirical studies have analyzed publicly-managed pension fund performance and governance structures (Iglesias and Palacios 2000; Carmichael and Palacios 2003; Mitchell and Useem 2000), and there are also several empirical studies analyzing the investment performance of public pension funds (Mitchell and Hsin 1997; Mitchell and Hustead 2000; Mitchell and Smith 1994; Useem and Mitchell 2000). Nonetheless, relatively little has been written on how one might link public sector pension investments to the specific structure of pension obligations that the funds face. Table 5 provides a comparison of the asset allocations of four publicly-held pension funds that do report their data in a public manner. The first two of these, the Canadian and Swedish plans, are essentially funded add-ons to national social security programs; this drives their relatively heavy portfolio concentration in foreign equities. The Korean and Japanese funds, by contrast, represent a

\footnotetext{
${ }^{4}$ In a defined-contribution system, the gains from increased pension fund earnings are distributed to retirees. Hence, young individuals start to save less since they expect higher pension benefits in the future. This, in turn, reduces the current capital stock and social welfare. In a defined-benefit system, increased pension fund earnings reduce payroll taxes. In response to increased current income, young individuals increase their savings, and hence, the current capital stock increases (Abel 2001).

${ }^{5}$ Some researchers (Barro 1979) view such a "demographic dividend" as the natural result of optimal tax smoothing. Yet the timing is critical: because social security taxes are tied to benefits payable far into the future, these tax collections generate large current financial reserves in the control of the public sector making them potentially at risk for spending on other purposes.
} 
demographically-driven temporary accumulation of contributions held mainly in domestic securities. This latter pattern is consistent with the fact that these funds' liabilities are also denominated in domestic currencies though it is unclear whether a formal portfolio optimization reflecting this aspect of the liability profile has been undertaken. In the case of Japan, publicly-held pension resources amount to about 30\% of GDP, a substantial amount responsive to the rapid aging of the Japanese population. Yet the fund falls far short of what is needed to pay future liabilities: KNH system liabilities of 550 trillion yen are several times larger than the government's old-age system reserve fund of around 179 trillion yen (Takayama 2006). Also, estimates suggest that the future shortfall might be substantially reduced through superior investment of these resources. ${ }^{6}$ Table 5 here Public Pension Fund Asset/Liability Considerations. Many analysts who work on private-sector pensions have concluded that some form of asset-liability joint management works best if one links investment policy and payout promises (c.f. Blake 2006). It is striking, therefore, that the vast majority of discussions of SWFs as well as publicly-managed pensions are silent about the need to link portfolio management goals to any particular obligation stream. One recent study by Maurer et al. (2008) investigates how a tax-sponsored public pension fund might invest pension contributions to relieve government budgets taking into account the risk and rewards from capital market diversification. While the analysis is a case study of a German civil servant pension, the more general contribution of the work is that it explicitly models the pension fund manager's appetite for risk and reward.

An outcome of that study is that it provides recommendations for portfolio investments which control the expected economic costs of providing the promised pensions, while at the same

\footnotetext{
${ }^{6}$ Lu et al. (2007) suggests that a 1 percentage point increase in returns, from $3 \%$ to $4 \%$, might bolster by 11 times the system's reserves in the year 2100 .
} 
time controlling investment risk. Both the expectation and the Conditional Value-at-Risk of economic pension costs are simulated using a stochastic simulation process for pension plan assets, allowing the authors to simultaneously set both the optimal contribution rate and the optimal capital market allocation. Of key importance is the fact that the plan sponsor may occasionally be forced to make supplementary contributions, which, as in the real world, brings with it a penalty.

Conversely, the authors also prohibit the public pension from being used as a hedge fund, so excess assets are withdrawn according to a pre-set rule. In the German case, the authors demonstrate that the optimal pension fund investment strategy given a 20 percent of salary contribution rate requires investing the public fund 30 percent equities and 70 percent in bonds. ${ }^{7}$

Naturally specific portfolio allocations must vary with capital market parameters, but the general approach is useful in making explicit a public fund manager's performance objectives when developing fund investment policies. Furthermore, given the nature of publicly-managed funds, when managers make their portfolio allocation decisions, the objective function must surely include intergenerational considerations (Weinberger and Golub 2007). ${ }^{8}$ Just as in the case of corporate pensions, this will require developing dynamic multi-period simulation models which take into account both the risks and returns associated with risky investment including Value-at -Risk models. ${ }^{9}$

\section{Good Management Practice in Public Investment Funds}

\footnotetext{
${ }^{7}$ Current taxpayers only have to pay regular contributions of 15 percent but the portfolio is invested 43 percent in equities. In this way future generations may benefit from contribution holidays and withdrawals, while providing an acceptable level of risk of supplementary contributions resulting from under-funding. For a related model see Haberman et al. (2000)

${ }^{8}$ In the US of late, the question of how to value public pension liabilities has become quite fraught (Pension Research Council 2008), particularly regarding whether these should be 'marked to market' using risk-free discount rates.

${ }^{9}$ In an interesting extension, Gray (2007) proposes that governments should move to using value at risk for all macroeconomic risks, by building a comprehensive national balance sheet and simulating national assets, liabilities, and contingent claims.
} 
The literature on what constitutes good management in public investment funds has thus far focused primarily on public sector pensions rather than publicly-managed asset pools more generally. One reason is that, until fairly recently, public pensions were the main form of publiclymanaged funds. For instance, Palacios (2002) estimated that such reserves amounted to around one-quarter of world GDP, mainly held in the US. Another reason is that there is a paucity of data on sovereign wealth funds, which we will discuss in greater detail below. In any event, we will argue in this section that many of the same governance principles apply to all forms of publiclymanaged investment pools (Impavido 2005).

Management practice in the public sector context can be described using three sets of standards initially proposed by the World Bank: Governance, Accountability, and Investment practices, referred to here as the GAI scores. Of these three components, governance refers to "the systems and processes by which [an entity] manages its affairs with the objective of maximizing the welfare of and resolving the conflicts of interest among its stakeholders” (Carmichael and Palacios 2003:7). Accountability refers to the process by which governance outcomes and decisions are reported and disclosed to stakeholders. For instance, a public pool invested in this way would provide access to information about funding shortfalls, conduct publicly-reported audits, and disclose consultancies and contractual arrangements. Investment practices refer to the process of developing investment profiles that balance risk and return, taking into account liabilities where these have been made explicit. Naturally in the case of pension reserves, benefit promises constitute the liability profile as noted above.

The literature on corporate governance serves as a useful point of departure in framing the discussion of public fund management, beginning with Jensen and Meckling (1976) and recently surveyed by Shleifer and Vishny (1997). Generally speaking, the problem is cast in a principal- 
agent framework where stakeholders must be protected against possible strategic actions by managers who may act in their own best interest unless they are constrained. Empirical evidence has demonstrated the key role of good management practices in corporate performance: for example, Gompers et al. (2003), using a US database of some 1500 firms through the 1990s, shows that firms with stronger shareholder rights have higher market value, higher profits, and higher sales growth, as well as lower capital expenditure and fewer corporate acquisitions. In the emerging market context, Klapper and Love (2004) analyze firm level data across 14 emerging markets and find that better corporate governance is associated with better operating performance and market valuation. Importantly in the present context, they also find that governance provisions matter more in countries having weak legal environments.

In the corporate sector, controls to handle the principal-agent conflict revolve around clarity of objective, appropriate rules about conflict of interest, clear incentives/accountability for each player, and disclosure of decisions and performance. By contrast in the public sector, the challenge is that there is frequently no agreed-on metric by which agents (taxpayers, public sector employees) can readily measure the long-term performance of the principals acting on their behalf (policymakers). However if fund manager objectives are clear, corporate-type governance, accounting, and investment principles can still be applied and will go a long way to providing adequate information about performance. On the other hand, experience shows that government involvement in the financial sector is also susceptible to conflicts of interest and therefore, from a governance perspective, in need of special attention. Such conflicts can arise from the extensive participation of government in financial systems through its role as regulator and owner of financial institutions; as a (non-atomistic) market participant and fiduciary agent; and through direct interventions in the operations of the market. 
Public Pension Plan Management. To illustrate how good management practices apply to publicly-managed asset pools, Panel A of Table 6 reports a World Bank-developed checklist for GAI criteria pertinent to public pension managers (Carmichael and Palacios 2003). The governance questions are designed to avoid undisclosed conflicts of interest, ensure autonomy from political intervention, secure staff competence, and in general make the criteria comparable with private sector rules. The accountability scoresheet focuses on information communication, information credibility, and process transparency. And the investment criteria focus on potential conflict of interest issues, along with the dilemmas created by market dominance in particular sectors, or overall in a country. It is also worth nothing that, though this GAI checklist was developed specifically for public pension funds, it makes no explicit mention of the public plan's liability profile. ${ }^{10}$

Table 6 here

An alternative set of guidelines devised by the $\operatorname{OECD}(2005,2006$, and 2007) for pension managers is also summarized in Panel B of Table 6, reorganized here under our three GAI headings to emphasize the commonalities and differences. Clearly-defined responsibilities for various members of management, suitability of personnel, and control over conflict of interest, appear on both lists, while the OECD offers some useful additional performance benchmarks that do not appear in the World Bank guidelines. One relates to redress, or what happens when promises made are not kept. A second pertains to "self-investment," which the OECD sees as contrary to sensible diversification of investment risk. ${ }^{11}$ Thirdly, the OECD explicitly recognizes the importance of a

\footnotetext{
${ }^{10}$ Liabilities are mentioned in the Accountability checklist, in terms of open reporting.

${ }^{11}$ In the public pension context, "self investment" could be interpreted as purchase of own domestic government bonds. Whereas many countries do require their public pension reserves to be heavily invested in this asset class, it must be questioned when, for instance, Japan's GPIF recently suffered when the investment quality of national government bonds was downgraded. This may explain recent reports indicating that the Japanese may begin investing some portion of the nation's reserves as a soon-to-be created sovereign wealth fund (Lewis 2008; Pesek 2008).
} 
fund's liability profile in developing investment strategies and fund objectives. In this sense these guidelines bring together the purpose and conduct of the fund, more in keeping with the advice offered in the corporate sector. ${ }^{12}$

Sovereign Wealth Fund Management Principles. The need for strong public sector governance in SWFs arises from the same sources that call for strong corporate governance (Carmichael 2002). Of particular note is recent research by the Peterson Institute (PI) on public fund management which proposes a "scoreboard" for comparing management practices of Sovereign Wealth Funds (Truman 2008a, b). This approach identifies four categories of SWF management practice focusing on fund (1) structure, (2) governance, (3) transparency/accountability, and (4) behavior. The structure and transparency/accountability categories are further divided into subcategories, such that in total, there is a total of 33 yes/no questions where either a 10.50 , or 0.75 ). Using this formulation the author ranks SWFs across 31 countries. This tally shows that New Zealand's Superannuation Fund tops the list followed by Alaska’s Permanent Fund, while at the bottom are the Abu Dhabi Investment Authority and Corporation of U.A.E. and the Qatar Investment Authority of Qatar.

This approach offers a useful way to systematize thinking about this relatively new corpus of public sector activity (a full list of variables and funds by name appears in Appendix I and II). To elaborate somewhat on how the scoring works, under the heading structure, the rubric identifies SWF clarity of objective, source of funding, and investment strategy. Topics addressed cover communication of the fund's objective, the specification of both sources and uses of funds, whether there is frequent intervention in source and use (presumably an indicator of multiple or expedient objectives in fund use), and the fund's relationship with the broader government budget. Clarity of

\footnotetext{
${ }^{12}$ Alternatively, SWF outcomes could be developed using the proposed voluntary guidelines for private equity firms recently drawn up by The Walker Group (Walker 2007). This group, however, seeks to emphasize communication of decisions and outcomes, rather than to implement decision-making structures or measure suitability of investment outcomes.
} 
investment strategy and separation from international reserves are also considered. From these elements, the picture that emerges has a "good” SWF being the public investment fund that has long term objectives other than strictly currency stabilization, explicitly or implicitly linked to some intertemporal allocation and/or distributional objective. Relating this to the elements of good management we have already identified, structure in the PI terminology encompasses some elements of governance along with investment strategy. The question of the fund's objective, and its scoring, is subject to caveat. This is because most funds examined in the PI study scored positively on this, but there was no attempt to link the stated objective with any other practice. Therefore the tally gives credit to a fund that explicitly lists its objectives, but it does not then additionally credit funds where other aspects of management practice support the stated objective, nor does it penalize funds where they do not.

In the PI formulation, the second heading, governance, speaks to the independence of the fund's investment strategy and the independence of the role of manager in executing investment strategy. Also under this rubric indicators for the existence of corporate responsibility and ethical guidelines are included, as well as indicators of whether the policies are publicly announced and followed. The notion of governance falls somewhat short of what might be expected given the corporate governance literature. For instance, there is no inquiry about the role of the governing board, or about the incentives available to operational roles in the organization.

The third major category proposed in the PI index pertains to how the SWF behaves in terms of transparency/accountability. Matters considered include reporting on activities and performance, public disclosure of investment portfolios, geographic location of direct investments, specific investments, currency of investments, and the identity of investment agents. The category also includes information about audits, regularity, public availability, and independence. The final PI 
category, behavior, asks about the nature and speed of adjustment of the SWF portfolio, and this is the least clearly explained. It should be noted that of the 33 PI questions, 14 fall under the transparency heading, and several of the questions listed under the structure heading could also plausibly be placed there as well. While this is an important component of overall fund management, the fact that only five items are included under the governance heading is rather arbitrary and most likely incomplete.

Below we will use these scoreboard measures as a way to begin to link SWF performance measures to factors that might drive these outcomes. It must be noted again here that the PI scoreboard is again silent on the links between management of assets and liabilities, which could be deleterious to fund performance inasmuch as investment policy is likely to vary depending on the objectives of the funds. This is generally because most SWFs funds do not explicitly state their objectives, whereas for public pensions, the benefit streams that consist of the funds' liabilities can be (more or less) valued cleanly. Even then, it is often the case that pension system liabilities tend not to be well-integrated into investment policy.

\section{Do Public Management Practices Affect Performance?}

Next we turn to a review of studies seeking to show how public fund management practices shape key outcomes. Inasmuch as most of the work on management practices focuses on corporate performance, we begin with an overview of this topic, and then we turn to a discussion of what is known about management of public sector funds.

Empirical research tying corporate management practices to firm-level outcomes is extensive. Much of the research through the mid-1990's is reviewed by Schleifer and Vishny (1997); since then, additional studies have emerged in response to the 2002 Sarbanes-Oxley Act 
(SOX) requiring US public companies to institute a range of procedural and structural reforms intended to enhance stakeholder confidence in the post-Enron era. The range of outcomes addressed in this literature is vast, including the corporation's return on assets, market valuation, stock returns, success at making acquisitions, and Tobin’s Q (or the firm’s market value of assets as a proportion of the replacement value of its assets), among others. ${ }^{13}$ The measures of 'good managerial practice' used by empirical analysts are several, and include most prominently key metrics of corporate governance. This, per Schliefer and Vishny (1997: 737), refers to the "ways in which suppliers of finance to corporations assure themselves of getting a return.” In particular, the literature emphasizes how investors may gain power through legal protection (e.g. via protection of minority rights and limits on managerial self-dealing), and also via large investor blocks which control managerial behavior directly. Accordingly, the literature has found important relationships between countries' legal efficacy scores, which indicate whether an enterprise is founded on common or civil law, and variables indicative of shareholder control rights. Many studies also examine policies regarding transparency and accountability, on the argument that rules enhancing financial reporting are likely to result in better protection for the investor.

The literature on public enterprise management builds on this private sector foundation in seeking to craft indicators of good-quality management and relate them to successful public firm outcomes. One problem is that public entities often do not conform to private-sector accounting and reporting standards, and another is that output measures used in the private sector frequently have no counterpart in the public sector. Nevertheless analysts have found it natural to use for public sector entities the same principal-agent framework mentioned above and popularized in the

\footnotetext{
${ }^{13}$ For a recent review of the empirical governance literature see Michaud and Magaram (2006); among the most cited studies are Gompers et al. (2003) and Schliefer and Vishny (1997). There are also numerous examinations of the links between good management practices and executive compensation which are beyond the scope of the present study; a recent review includes Gerakos (2007).
} 
corporate world. In this context, the taxpayer and other members of the public represent the principals, while the agents are the government managers guiding the public enterprise (c.f. Ambachtsheer 2007b; Coronado et al. 2003). Thus in theory it would be feasible to evaluate whether particular management practices can shape outcomes of public sector enterprises, though with some adaptations depending on the type of public firm in question.

In the specific case of public entities of key interest here - namely public pension plans and sovereign wealth funds - the conventional measures of corporate outcomes such as shareholder wealth, firm profitability, and market share do not readily apply. For this reason, analysts have turned to other metrics to determine whether public sector enterprise performance is enhanced as a result of particular management practices. For instance one outcome of interest might be investment-related. In the simplest case, for instance, public pension funds which hold some assets can report their target annual return (e.g. 3.2\% in the case of the Japanese GPIF). More elaborately perhaps, some public plan managers may indicate their risk-adjusted returns vis a vis some benchmark. Relatively few focus on the dynamic path of liabilities as well as assets, about which we say more below.

The few existing studies linking public pension plan investment strategies and investment returns tend to show that these are often influenced by governance factors such as board composition (Mitchell and Hsin 1997). For instance, having more retirees tends to lower performance due to greater weighting toward a fixed income portfolio. Again in public pensions, Useem and Mitchell (2000) show that governance variables account for over 20 percent of the cross-pension plan variation in investment strategies, which in turn are positively associated with subsequent investment return performance on the pension fund assets. Yang and Mitchell (2008) examine how pension plans' funded status (or the ratio of plan assets to liabilities) and investment 
returns respond to measures of pension board composition, management practice, reporting practice, and investment practice. They show that many pension boards have political appointees as well as active and/or retired workers on the roster, both of which can be problematic when these board members may not be particularly financially expert.

Another issue is that sometimes public entity trustees have used fund assets to further their own (or their party's) political/social objectives. Hsin and Mitchell (1997) find that several pension management factors are statistically significant and economically important. For instance, ceteris paribus, having more plan participants on the pension board, whether retired or active, reduces plan funding levels and the point estimates imply that adding an additional active member reduced stock funding by 0.7 percentage points, while adding one more retired member decreases funding by 1.7 percentage points. Further, investment yields on the public pension plan assets appear significantly lower when retiree representation increases, perhaps due to lack of investment expertise. Enhanced pension reporting, including making annual reports on financial, actuarial, statistical, and investment information to stakeholders, can improve returns by 2.1 percentage points annually.

Research on public pensions and mutual funds by Ambachtsheer (2007a, b) uses as the dependent variable "net value added" or the fund's gross investment return minus its benchmark return and the fund's total expenses. This outcome proves statistically related to a lengthy list of 45 measures of governance quality obtained by interviewing public fund CEOs. Ambachtsheer (2005: 196-7) reports that of the entire lengthy list of indicators, six governance-related and five management-related measures in his CEO survey are significant. In that author's words, "statistically significant governance statements (are)...related mainly to effective fiduciary behavior and selection processes, clarity in delegation of authority, and a high level of trust between the governing and managing fiduciaries. The statistically significant management statements (are) 
related mainly to clear strategic positioning and to the effective development and execution of the fund’s strategic plan.”

How Can Fund Objectives Be Incorporated? The studies of public funds mentioned above focus primarily on asset-related outcomes such as returns and funding patterns. ${ }^{14}$ Yet as we have argued above, one should also consider integrating the asset/investment management effort with the evolution of plan liabilities. For instance, in the case of a public pension system, the goal is generally agreed to ensure that retiree benefits can be paid without large and unexpected increases in the cost of maintaining the solvency of the system. Nevertheless, as Ambachtsheer (2005:198) emphasizes, “fund managers of late have made no measurable effort to take into account the financial characteristics of their liabilities when structuring their fund policy portfolios.” Indeed, a reason that managers may have found it difficult to do so is that it may be troublesome to convert the broad objective of "paying pension benefits” into specific fund management rules and performance criteria. Sometimes the liability path will be difficult to model and simulate. Or public pension plan investment policy may be set independently of liability paths on purpose; for instance this is the case for the US Social Security Trust Fund which is permitted to hold only special issue government bonds. ${ }^{15}$ Still an additional reason that asset-liability management is not undertaken in a concerted, coherent form may be because policymakers may not wish to make explicit what their risk appetite is in terms of shortfalls and surpluses.

Nevertheless, in the last several decades, great strides have been made in analysts’ ability to model and solve for ways to implement asset-liability models, and this could be even more useful in the future. Of course, to select an appropriate investment strategy in the face of these stochastic

\footnotetext{
${ }^{14}$ Insofar as we are aware, there are very few studies that report investment performance for the SWFs that are not pension related, much less risk adjusted or benchmark-linked returns. One of the view reporting public pension returns by country and time period is that of Carmichael and Palacios (2002).

${ }^{15}$ For a discussion of investment practices of 15 other publicly-managed pension fund systems see UN (2007).
} 
liability patterns, policymakers must make explicit their risk budgets, or how they balance the unavoidable and dynamic tensions between investment returns, benefit payments, and contribution requirements. Such risk budgets must take into account both the uncertainty of system revenues, including investment returns earned on pension fund assets, and stochastic pension liabilities as discussed above. Recent discussion on these points includes including Moore (2007) and Boender et al. (2001), the latter of whom implement this approach for Dutch pension funds. Maurer et al. (2007) examine public sector employee pensions in Germany. In general, these evaluations must specify how plan outlays will depend on projections of earnings, patterns of labor market attachment, retirement trends, longevity forecasts, and many other factors. ${ }^{16}$ In turn, investment portfolios can be optimized to take liability variations into the decision of how to structure the asset mix given capital market trends. Other examples of asset-liability management in the public pension fund arena include the work of Bogentoft et al. (2001) and several of the excellent papers in Ziemba and Mulvey (2001).

One of the most clearly exposited papers in this vein is by Merton (2001), who implements this approach in the case of a university endowment fund. His model is relevant to the present research as it recognizes that such entities draw not only on their endowment pools but may also count on other cash flows including contributions from donors, tuition and other business income, and grants. He makes the crucial point that these revenue flows are also volatile and so should be modeled as part of the plan’s resources. This approach has a logical parallel in the case of public pension funds and SWFs which may receive contributions from a variety of sources, while they can also draw down their investment pools to meet specific obligations. Insofar as some of the

\footnotetext{
${ }^{16}$ Other examples of this in the US include efforts by the Congressional Budget Office (CBO 2004) to build a stochastic model to evaluate the impacts of possible changes in the national old-age benefits program. The US Social Security Administration (US SSA 2008) has also developed a stochastic model used to project probability distributions for future outcomes of the system's financial status.
} 
contribution sources have the same risk characteristics as equities, for instance, the entity may decide to invest less in stock. In its simplest form, the Board’s preference structure for the university is taken to be a lifetime utility function of the form:

$$
\operatorname{Max}_{0}\left[\int_{0}^{\infty}\left(Q_{1}, \ldots Q_{m}, t\right) d t\right]
$$

where $\mathrm{Q}_{\mathrm{j}}(\mathrm{t})$ is the quantity of the preferred activity $\mathrm{j}$ (e.g. education, research, etc) in which the firm engages at time t, and the utility function is well behaved. The entity is assumed to be indefinitely lived, making the upper limit on the integral infinity. (Other more complex formulations can be permitted). The remainder of the model specifies cost functions for producing the firm's outputs, and dynamics for cash flows for contributions and investment earnings. Over time the university selects a vector of activities Q, and a portfolio allocation in its endowment fund, to achieve maximum utility (1). Similarly, a pension fund can also be modeled as seeking to pay benefits, subject to constraints over revenue, investment patterns, and perhaps some risk aversion regarding extreme cash shortfalls that would otherwise require massive transfusions of new cash. To the extent that a university (in Merton’s case) or a pension fund (in our case) faces different risk profiles for its revenue streams and different cost profiles, this will produce different optimal investment strategies for the endowment pools.

The important lesson that emerges from these analyses is that good management practice has a material positive impact on corporate performance, but this cannot yet be shown for publiclymanaged funds in view of the dearth of data on this topic. ${ }^{17}$ Furthermore, most studies of public fund management have emphasized only financial or actuarial outcomes such as net returns, funding, or investment expenses. Only a handful have constructed clearly-formulated models that

\footnotetext{
${ }^{17}$ In Ambachtsheer's (2005) words, the research is suggestive of “a noteworthy convergence between what are deemed to be generally good governance and management practices in the for-profit and not-for-profit sectors as a whole and what we now find is important in the governance and management of pension funds.”
} 
link fund contributions and investments to measures of anticipated future benefits that these funds seek to deliver. So the challenge is to "determine a jointly optimal dynamic strategy for the asset and liability instruments which balances the interests and requirements of all agents involved” (Boender et al. 2001:564). In particular, public fund managers must take into account the ability of the fund to meet other objectives (e.g. not raising taxes too sharply on any given generation in the event of a revenue shortfall).

\section{Empirical Analysis of Determinants of Public Investment Fund Management}

Next we turn to a brief empirical examination of key factors associated with variation in observed SWF management attributes. We focus on the measures of governance, accountability, and investment (GAI) described above and explore what might influence how these asset pools function along these dimensions. A first implementation step requires us to group the multiplicity of scores reported on SWFs in the PI scoreboard into our three preferred headings. We do so by computing the G, A, and I scores by summing the subcomponents for each of the SWFs, and then we add these to form an aggregate GAI index. ${ }^{18}$ Next, we link the GAI indicator using multivariate regression models to factors descriptive of the national environments in which these publicly managed funds are found, following the empirical strategy outlined in the corporate governance literature described above. Our particular focus is on indicators of country-specific governance and political participation, human capital and the business environment, and demographic controls to be

\footnotetext{
${ }^{18}$ Appendix I and II indicate how we reallocate the PI scoreboard items into our three GAI categories. Accountability is quantitatively the most important of the three components, comprising 15 of the 33 questions on the PI list. We omit the PI indicator of whether a SWF is integrated within the overall government budget. In analysis not reported here in detail, we conducted principal components analysis on the entire vector of underlying scores to determine whether any subset of factors is particularly useful in summarizing larger set of analysis. However this exercise does not return a few key factors that explain most of the variability, so we use GAI and its subcomponents as our independent variables. Not surprisingly, Appendix IV shows that the governance, accountability, and investment measures of fund success are strongly positively correlated.
} 
described in more detail below. We report OLS regression coefficients for the aggregate GAI scores using the following framework:

GAI score $=\mathrm{f}$ (National governance and political participation indicators; Indicators of human capital and business environment; Demographic controls).

The national governance and political participation variables employed in this formulation are derived from the World Bank Governance Indicators (WBGI; see Kauffman et al. 2007) which include six factors relating to different aspects of governance: Voice and Accountability; Political Stability; Government Effectiveness; Regulatory Quality; Rule of Law, and Control of Corruption. Country-specific measures of the quality of human capital and the efficacy of the business environment are taken from World Economic Forum indices of global competitiveness (GCI; see Sala-i-Martin et al. 2007). The GCI indicators focus on economic performance including macroeconomic stability, as well as education and business sophistication. To render the many World Bank and GCI indices more tractable, we use Principal Component Analysis (Hamilton 2006) to combine them into a Modified World Bank Governance Index (MWBGI) and Modified Global Competitive Index (MGCI). In alternative models, we substitute some of the underlying factors indicative of the political environment for the overall indexes; these include "Voice and Accountability” measuring participation in government and freedom of expression, and “Government Effectiveness” which measures civil service quality. The rationale is that freedom of expression should enhance all dimensions of the GAI score because of the greater risk of public exposure for incompetence or fraud. Similarly, high quality public service should be able to deliver better public sector management. Market efficiency can be proxied by a business sophistication metric, on the grounds that this would be positively associated with public investment fund accountability. A nation's legal environment can be represented by regulatory quality (by which we mean policies that enhance private sector performance) or rule of law (by which we mean a strong 
judicial system), following Klapper and Love (2004) and Shleifer and Vishny (1997) who show that better legal systems help protect shareholder rights.

To this reasonably conventional list of control variables we add a measure of a nation’s oldage dependency ratio, to test whether the performance indicators are related to intertemporal objectives even if these are implied rather than explicit. In a few cases, some countries had multiple SWFs with differing GAI scores. To handle this, we compute an asset-weighted average of the GAI scores to come up with a single combined fund metric for that country. Also a few small countries had exceptionally high GAI scores along with very low GCI and Governance scores. ${ }^{19}$ Inasmuch as these developing/emerging market funds are probably influenced by international organizations’ views of good fund management practice, we control on the log of SWF assets to reflect this diversity. Variable definitions and descriptive statistics on our empirical variables are reported in Appendix III.

The multivariate coefficient estimates for the GAI model appear in Table 7. As there are only 26 SWFs for which full data are available, we are parsimonious in selecting which explanatory variables to include. We see that larger funds tend to score lower on the GAI ranking when statistically significant. We also see that better governance is associated with a higher old-age dependency ratio in columns 1-3, suggesting that when the elderly grow relatively more numerous, their voice tends to be reflected in larger economic claims driving better SWF management. Curiously, however, only the current dependency ratio is statistically significant, while projected old-age ratios tend not to be.

Turning next to the governance and economic variables, Column 1 indicates that the World Bank governance index is positive and significant at only the $10 \%$ level, while the GCI index is not significant and negative. Columns 2-4 further explore the relationship between relevant national

\footnotetext{
${ }^{19}$ This list includes Azerbaijan, Botswana, Timor Leste and Trinidad and Tobago.
} 
characteristics and the GAI scores, where we see not much statistical association between good SWF governance and business sophistication, regulatory quality, and rule of law. Only the Voice and Accountability factor is positively associated with good fund governance.

\section{Table 7 here}

Our results thus differ from one recent study on private pension funds by Servaes and Khorana (2007), who argue that more efficient mutual funds are found in countries with betterfunctioning judicial systems and more educated populations. Overall we find little evidence that national characteristics strongly shape the governance, accountability, and investment structures of national sovereign wealth funds.

\section{Conclusions}

We have examined management practices for publicly-managed asset pools, seeking to draw lessons about how these institutions might better manage their funds. Our review of the main types of public investment pools having long-term objectives indicates that pension fund and SWFs share many commonalities with regard to their objectives and rationales. Nevertheless, empirical evidence on these outcomes for publicly-managed asset pools is scarce, and what there is tends to be silent on the structure of liabilities implicitly or explicitly associated with these funds. Building on prior studies, we devise performance criteria regarding fund governance, accountability, and investment policies. When we relate these GAI measures for sovereign wealth funds to a range of national governance and political participation indicators, measures of human capital and business environment, and demographic controls, we find that the current aged dependency ratio appears to be a consistently important explanatory factor associated with good management. This suggests that 
nations subject to the most pressure from population ageing tend to be more careful with SWF governance.

Policy analysts would benefit from better understanding of what constitutes best practice for the management of the substantial global reserves held in SWFs and public pensions. To this end, information is needed linking performance indicators to goals, presumably including good measures of intertemporal and intergenerational objectives. Unfortunately, as SWFs have grown, they appear to be demonstrating an increasing risk appetite with little transparency, and virtually no clarity of objectives. As a result, their growth is spurring debate in recipient countries and among financial market intermediaries, along with calls for regulatory reform in the international sphere and a move toward financial protectionism or even the explicit prohibition of SWF investments. For instance, the European Commission is drafting a plan to prohibit non-European Union members from investing in the European energy business. German Chancellor Angela Merkel has mentioned designing a system similar to that implemented in the US where a governmental Committee on Foreign Investment must review and approve foreign-based investments that might be deemed a threat to national security (EurActive.com 2007). Such financial protectionism might be avoided if these publicly-managed investment pools were made more transparent, clearer in their objectives, and more accountable to the many stakeholders in these funds. 


\section{References}

Abel, Andrew. 2001. "The Social Security and Trust Fund, the Riskless Interest Rate and Capital Accumulation.” Risk Aspects of Investment-based Social Security Reform. Eds. J.Y. Campbell and M. Feldstein. Chicago: The University of Chicago Press: 153- 93

Ambachtsheer, Keith. 2007a. "The Ideal Pension Delivery Organization.” Presented at the Conference on "Exploring the Future of Pension Finance and the Dynamics of Institutional Pension Reform" sponsored by De Nederlandsche Bank, Netspar, and the International Organization for Pension Supervision, March 22-23 2007, Amsterdam.

Ambachtsheer, Keith. 2007b. Pension Revolution: A Solution to the Pensions Crisis. John Wiley \& Sons.

Ambachtsheer, Keith. 2005. "Why Pension Fund Management Needs a Paradigm Shift.” In Reinventing the Retirement Paradigm. Eds. Olivia S. Mitchell and Robert L. Clark. Oxford: Oxford University Press: 188-205.

Arrau, P. and S. Claessens. 1992. “Commodity Stabilization Funds.” World Bank Policy Research Working Paper. Washington DC: World Bank.

Auerbach, Alan J. and Ronald Lee. 2008. "Welfare and Generational Equity in Sustainable Unfunded Pension Systems.” Presented at the NBER Summer Institute, Cambridge, MA.

Australia Future Fund. 2008. Annual Report. www.futurefund.gov.au/

Barro, R. J. 1979. “On the Optimal Level of Public Debt.” Journal of Political Economy, 87 (5): 940-971.

Blake, D. 2006. Pension Finance. London: Wiley.

Boender, CGE, PC van Aaslst, and F. Heernserk. 2001. "Modeling and Management of Assets and Liabilities of Pension Plans in The Netherlands.” In Worldwide Asset and Liability Modeling. Eds. William Ziema and John Mulvey. Cambridge: Cambridge University Press: 561-580.

Bogentoft, E., H. E. Romeijn, and S. Uryasev. 2001. “Asset/Liability Management for Pension Funds Using CVaR Constraints.” Journal of Risk Finance 2(3): 57-71.

Bohn, Henning. 2002. "Government Asset and Liability Management in an Era of Vanishing Public Debt” Journal of Money, Credit and Banking 34(3): 887-933.

Bohn, Henning. 1999. "Should the Social Security Trust Fund Hold Equities? An Intergenerational Welfare Analysis.” Review of Economic Dynamics 2: 666-697.

Canada Pension Plan Investment Board. 2008. Annual Report.www.cppib.ca

Carmichael, Jeffrey and Robert J. Palacios. 2003. “Managing Public Pension Funds: A Framework.” Paper presented to 2nd Public Pension Fund Management Conference. World Bank, Washington DC, May 2003.

Congressional Budget Office (CBO). 2004. The Outlook for Social Security. US Congress. June. http://www.cbo.gov/ftpdocs/55xx/doc5530/06-14-SocialSecurity.pdf 
Coronado, Julia L., Eric M. Engen and Brian Knight. 2003. "Public Funds and Private Capital Markets: The Investment Practices and Performance of State and Local Pension Funds.” National Tax Journal 56(3): 579-94.

Das, U. S. 2007. “Sovereign Wealth Funds.” IMF Global Financial Stability Report: 45-50.

Davis, Jeffery M., Rolando Ossowski, James Daniel, and Steven Barnett. 2001. "Stabilization and Savings Funds for Non-renewable Resources: Experience and Fiscal Policy Implications.” IMF Occasional Paper 205. International Monetary Fund, Washington, D.C.

Devlin, Julia and Sheridan Titman. 2004. “Managing Oil Price Risk in Developing Countries.” World Bank Research Observer 19: 120 - 139.

Economist. 2007. “The World’s Most Expensive Club.” May 26.

Economist. 2008. “The Invasion of the Sovereign Wealth Funds.” January 19.

EurActiv.com. 2007. “EU to Consider Protection from State-funded Foreign Takeovers.” 24 July. www.euractiv.com/en/innovation/eu-consider-protection-state-funded-foreign-takeovers/article165798?_print

Gerakos, Joseph. 2007. “CEO Pensions: Disclosure, Rent Extraction, and Incentive Contracting.” Pension Research Council Working Paper WP2007-05. The Wharton School.

Gerlagh, Reyer and Michiel A. Keyzer. 2001. "Sustainability and the Intergenerational Distribution of Natural Resource Entitlements.” Journal of Public Economics 79: 315-341

Gompers, Paul A., Joy L. Ishii, and Andrew Metrick.2003. “Corporate Governance and Equity Prices.” Quarterly Journal of Economics 118(1):107-155.

Gray, Dale. (2007). “A New Framework for Risk and Sovereign Wealth Management.” In Sovereign Wealth Management. Eds. J. Johnson-Calari and M. Rietveld. London: Central Banking Publications: 117138.

Haberman, Steve, Z. Butt, and Ch. Megaloudi. 2000. "Contribution and Solvency Risk in a Defined Benefit Pension Scheme.” Insurance: Mathematics and Economics 27: 237-259.

Hamilton, Lawrence C. 2006. Statistics with Stata (Updated for Version 9). Brooks/Cole.

Hsin, Ping-Lung and Olivia S. Mitchell. 1997. "The Political Economy of Public Pensions: Pension Funding, Governance, and Fiscal Stress.” Revista de Analisis Economico. Eds. P. Arrau \& K. SchmidtHebbel. 9 (1): 151-168.

Iglesias, Augusto and Robert J. Palacios. 2000. "Managing Public Pension Reserves. Part I: Evidence from the International Experience.” Social Protection Discussion Paper 3. Washington, D.C.: World Bank.

Impavido, Gregorio. 2005. “Governance of Public Pension Plans: The Importance of Residual Claimants.” Working Paper. The World Bank. info.worldbank.org/etools/docs/library/153011/6-Impavido(2004)04-02-13.pdf

India Employees' Provident Fund Organisation. 2008. Annual Report. http://epfindia.nic.in/epfbrief.htm

Ireland National Pension Reserve Fund Commission. 2006. Annual Reports and Financial Statements 2006. www.nprf.ie/Publications/NPRF Annual Report 2006.pdf 
Japan Government Pension Investment Fund. 2008. Annual Report. www.gpif.go.jp/eng/index.html

Jen, Steven. 2007. “The Definition of a Sovereign Wealth Fund.” Morgan Stanley. October 26. www.morganstanley.com/views/gef/archive/2007/20071026-Fri.html\#anchor5727

Jensen, William and Michael Meckling. 1976. "Theory of the Firm: Managerial Behavior, Agency Costs and Ownership Structure.” Journal of Financial Economics.

Kern, S. 2007. SWFs: State Investments on the Rise. Deutsche Bank Research. September.

Klapper, Leora and Inessa Love. 2004. “Corporate Governance, Investor Protection and Performance in Emerging Markets.” Journal of Corporate Finance, November.

Korea National Pension Fund. 2008. Annual Report. www.nps.or.kr

Kumru, C. S. and Athanasios C. Thanopoulos. Forthcoming."Social Security and Self Control Preferences." Journal of Economic Dynamics and Control.

Kuwait International Social Security Review. 1998. “Social Security in Kuwait.” International Social Security Review 51 (2): 57-61.

Lewis, Leo. 2008. “Japan to create £25bn sovereign fund as fears mount on global sub-prime loss.” The

Times. January 26. business.timesonline.co.uk/tol/business/industry sectors/banking and finance/article3254209.ece

Lu, Bei, Olivia S. Mitchell, and John Piggott. 2008. "Notional Defined Contribution Pension and Public Reserve Funds in Ageing Economies.” International Social Security Review. Forthcoming.

Lucas, Deborah. 2001. "Investing Public Pensions in the Stock Market: Implications for Risk Sharing, Capital Formation and Public Policy in the Developed and Developing World.”International Review of Finance. 2(3) September: 179-202.

MaCurdy, T. E. and John Shoven. 2001. “Asset Allocation and Risk Allocation: Can Social Security Improve Its Solvency Problem by Investing in Private Securities?” In Risk Aspects of Investmentbased Social Security Reform. Eds. J.Y. Campbell and M. Feldstein. Chicago: The University of Chicago Press.

Malaysia Employees' Provident Fund. 2008. Annual Report. www.kwsp.gov.my/index.php?ch=p2corporateinfo\&pg=en_p2corporateinfo_geninfo\&ac=1856

Matsui, Akira and Makiko Suzuki. “Japan's Public Pension Fund to Invest in Small Stocks.” Bloomberg June 13, 2007. www.bloomberg.com/apps/news?pid=20601101\&sid=af16cLNcW3a0\&refer=japan\#

Maurer, Raimond, Olivia S. Mitchell and Ralph Rogalla. 2008. “The Victory of Hope over Angst? Funding, Asset Allocation, and Risk-Taking in German Public Sector Pension Reform.” In Frontiers in Pension Finance. Eds. D. Broeders, S. Eijffinger, and A. Houben. Cheltenham: Edward Elgar.

Merrill Lynch. 2007. The Overflowing Bathtub, the Running Tap, and SWFs in Global Economy. Merrill Lynch.

Merton, Robert. 2001. “Optimal Investment Strategies for University Endowment Funds.” In Worldwide Asset and Liability Modeling. Eds. William Ziema and John Mulvey. Cambridge: Cambridge University Press: 371-396. 
Michaud, Dennis Wright and Magaram, Kate A. 2006. "Recent Technical Papers on Corporate Governance.” April. http://ssrn.com/abstract=895520

Mitchell, Olivia S. and Ping-Lung Hsin. 1997. “Managing Public Sector Pensions.” In Public Policy Toward Pensions, Eds. J. Shoven and S. Schieber. 20th Century Fund. Cambridge, MA: MIT Press: 247-266.

Mitchell, Olivia S. and Ping-Lung Hsin. 1997. 'Public Sector Pension Governance and Performance.' In The Economics of Pensions: Principles, Policies and International Experience. Ed. Salvador Valdes Prieto. Cambridge University Press: Cambridge: 92-126.

Mitchell, Olivia S. and Hustead, Edwin.2000. Pensions for the Public Sector. Pension Research Council. Philadelphia, PA: University of Pennsylvania Press.

Mitchell, S. Olivia and Robert Smith. 1994. "Pension Funding in the Public Sector.” Review of Economics and Statistics 76(5): 278-90.

Morgan Stanley Global. 2007. “How Big Could Sovereign Wealth Funds Be By 2015?” May 3.

Moore, James F. 2007. Changing Paradigms in Asset Allocation for Pension Plans. PIMCO.

Musalem, Alberto and Robert Palacios, eds. 2004. Public Pension Fund Management. Washington DC: World Bank.

New Zealand Superannuation Fund. 2008. Annual Report. http://www.nzsuperfund.co.nz

Norges Bank Investment Management. 2006. Government Pension Fund-Global Annual Report 2006. http://www.norges-bank.no/Pages/Report 65332.aspx

OECD. 2005. OECD Guidelines for Pension Fund Governance.

OECD. 2006. OECD Guidelines on Pension Fund Asset Management.

OECD. 2007. Pension Markets in Focus. November (4).

Olters, Jan-Peter. 2007. “Old Cures, New Approaches? Fiscal Benchmarks for Oil Producing Countries in Sub-Saharan Africa.” IMF Working Paper.

Oshio, Takashi. 2004. "Social Security and Trust Fund Management.” Journal of the Japanese and International Economies, 18 (4): 528-550.

Palacios, Robert. 2002. "Managing Public Pension Reserves part II: Lessons from Five Recent OECD initiatives.” Social Protection Discussion Paper Series, Social Protection Discussion Paper no. 0219, World Bank. www.worldbank.org/sp.

Patelis, A. 2007. “The Overflowing Bathtub, the Running Tap and SWFs.” Merrill Lynch Global Economics.

Pension Research Council. 2008. “The Future of Public Employee Retirement Systems.” Working Paper 2008-08, Wharton School. http://www.pensionresearchcouncil.org/publications/document.php?file=434

Pesek, William. 2008. “Japan's Economy Needs a Sovereign Wealth Fund.” Bloomberg.com. January 28. www.bloomberg.com/apps/news?pid=20601039\&sid=aAODASRjKLA8\&refer=home\# 
Rietveld, Malan and Robert Pringle. 2007. “The Evolution of Sovereign Wealth Management.” In Sovereign Wealth Management. Eds. J. Johnson-Calari and M. Rietveld. London: Central Banking Publication: $1-11$.

Sala-i-Martin, X., J. Blanke, M. D. Hanouz, T. Geiger, I. Mia, and F. Paua. 2007. "The Global Competitveness Index: Measuring the Productive Potential of Nations.” The Global Competitveness Report 2007-2008. Hampshire: Palgrave Macmillian: 3-51.

Scheherazade, Daneshkhu and James Blitz. 2007. “UK Warns Over Push for State Protection.” Financial Times. 25 July.

Servaes, Henri and Ajay Khorana. 2007. "Competition and Conflicts of Interest in the in the U.S. Mutual Fund Industry. LBS Working Paper. May.

Shabsigh, Ghiath and Nadeem Ilahi. 2007. "Looking Beyond the Fiscal: Do Oil Funds Bring Macroeconomic Stability?” IMF Working Paper.

Shleifer, Andrei and Robert W. Vishny. 1997. “A Survey of Corporate Governance” The Journal of Finance 52 (2): 737-783.

Singapore Central Provident Fund. 2008. Annual Report. mycpf.cpf.gov.sg/Members/home.htm

Sweden First AP Fund. 2008. Annual Report. www.ap1.se/en/About-AP1/

Takayama, N. 2006. “Reforming Social Security Pensions in Japan: Is NDC the Answer?” In Pension Reform-Issues and Prospects for Non-Financial Defined Contribution (NDC) Schemes. Eds. R. Holzmann and E. Palmer. Washington, D.C.: World Bank: 639-648.

Truman, Edwin. 2008(a). "A Blueprint for Sovereign Wealth Fund Best Practices." Peterson Institute Policy Review. Washington DC: Peterson Institute for International Economics.

Truman, Edwin. 2008(b). “The Rise of Sovereign Wealth Funds: Impact on US Foreign Policy and Economic Interests." Testimony before the Committee on Foreign Affairs, US House of Representatives. May 21.

Truman, Edwin. 2007(a). Sovereign Wealth Funds: The Need for Greater Transparency and Accountability. Washington, DC: Peterson Institute for International Economics.

Truman, Edwin. 2007(b). "Sovereign Wealth Fund Acquisitions and Other Foreign Government Investments in the United States: Assessing the Economic and National Security Implications.” Testimony before the Committee on Banking, Housing, and Urban Affairs, United States Senate. November 14.

United Nations (UN). 2008. World Population Prospects: The 2006 Revision Population Database. Population Division. esa.un.org/unpp/index.asp?panel=2

United Nations (UN). 2007. Responsible Investment in Focus: How leading public pension funds are meeting the challenge. Environment Programme Finance Initiative Asset Management Working Group and UK Social Investment Forum Sustainable Pensions Project 2007 Report.

US Social Security Administration (US SSA). 2008. "Stochastic Projections.” Social Security Online. Office of the Chief Actuary. http://www.ssa.gov/OACT/stochastic/. 
Useem, Michael, and Olivia S. Mitchell. 2000. "Holders of the Purse Strings: Governance and Performance of Public Retirement Systems.” Social Science Quarterly 81(2): 489-506.

Walker, David. (2007). “Guidelines for Disclosure and Transparency in Private Equity.” The Walker Working Group, London. www.walkerworkinggroup.com.

Watson Wyatt Worldwide. 2006. The World's 300 Largest Pension Funds. Washington, DC: Watson Wyatt Worldwide.

Watson Wyatt Worldwide. 2007. “The World's Sovereign Wealth Funds.” Washington, DC: Watson Wyatt Worldwide.

Weinberger, Fred and Bennett Golub. 2007. “Asset Allocation and Risk Management for Sovereign Wealth Funds.” In Sovereign Wealth Management. Eds. J. Johnson-Calari and M. Rietveld. London: Central Banking Publication: 71-102.

World Bank. 2008. Key Development Data and Statistics. http://go.worldbank.org/1SF48T40L0

Yang, Tongxuan (Stella) and Olivia S. Mitchell. (2008). "Public Pension Governance, Funding, and Performance: A Longitudinal Appraisal.” In Pension Fund Governance: A Global Perspective. Eds. John Evans and John Piggott. London: Edward Elgar: 179-199.

Ziemba, William and John J. Mulvey, eds. 2001. Worldwide Asset and Liability Modeling. Cambridge: Cambridge University Press. 
Table 1. List of Currency Stabilization Funds by Nationality and Size

\begin{tabular}{lcc} 
Country & Assets (US\$M' 2007) & Assets as \% of GDP \\
Algeria & 83,000 & 63.1 \\
Australia & 67,166 & 7.4 \\
Brazil & 155,617 & 11.8 \\
China & $1,334,590$ & 41.1 \\
Hong Kong & 136,267 & 65.9 \\
India & 220,223 & 20.0 \\
Indonesia & 49,406 & 11.4 \\
Japan & 907,346 & 20.7 \\
Korea & 250,667 & 26.2 \\
Libya & 64,000 & 112.2 \\
Malaysia & 91,240 & 48.9 \\
Mexico & 78,172 & 8.8 \\
Norway & 56,658 & 14.5 \\
Poland & 52,286 & 12.4 \\
Russia & 407,495 & 31.6 \\
Singapore & 144,056 & 89.3 \\
Taiwan & 266,287 & 69.5 \\
Thailand & 69,000 & 28.1 \\
Turkey & 67,000 & 10.1 \\
UK & 42,000 & 1.5 \\
US & 55,086 & 0.4 \\
\hline \hline
\end{tabular}

Sources: Merrill Lynch (2007), Truman (2007a, b), and World Bank (2008). 
Table 2. Sovereign Wealth Funds by Name, Year of Inception, Source, Stated Objective, and Size

\begin{tabular}{|c|c|c|c|c|c|c|}
\hline Country & Fund Name & $\begin{array}{l}\text { Year of } \\
\text { Inception }\end{array}$ & Sources & Objectives & $\begin{array}{c}\text { Assets } \\
\text { (USM\$'2007) }\end{array}$ & $\begin{array}{c}\text { Assets } \\
\text { as \% of } \\
\text { GDP }\end{array}$ \\
\hline UAE & Abu Dhabi Investment Authority and Council & 1976 & Oil revenues & Savings & 875,000 & 454.3 \\
\hline Singapore & Government of Singapore Investment Corporation & 1981 & Trade surpluses & Savings & 330,000 & 204.5 \\
\hline Singapore & Temasek Holding & 1974 & Fiscal surpluses & Savings & 110,000 & 68.2 \\
\hline Norway & Government Pension Fund - Global & 1990 & Oil revenues & $\begin{array}{l}\text { Savings \& } \\
\text { stabilization }\end{array}$ & 375,000 & 95.8 \\
\hline China & State Foreign Exchange Investment Corporation & 2007 & Trade surpluses & Savings & 200,000 & 6.2 \\
\hline China & Central Hujin Investment Corporation & 2003 & Trade surpluses & Savings & 100,000 & 3.1 \\
\hline Kuwait & Kuwait Investment Authority & 1953 & Oil revenues & $\begin{array}{l}\text { Savings \& } \\
\text { stabilization }\end{array}$ & 213,000 & 191.3 \\
\hline Russia & Stabilization Fund of the Russian Federation & 2003 & Oil revenues & Stabilization & 128,000 & 9.9 \\
\hline Russia & Future Generation Fund of the Russian Federation & 2008 & Oil revenues & Savings & 32,000 & 2.5 \\
\hline $\begin{array}{l}\text { U.S. } \\
\text { U.S. }\end{array}$ & $\begin{array}{l}\text { Alaska Permanent Reserve Fund Co. } \\
\text { New Mexico State Investment Office Trust Funds }\end{array}$ & $\begin{array}{l}1976 \\
1958\end{array}$ & $\begin{array}{l}\text { Oil revenues } \\
\text { Royalties on State lands }\end{array}$ & $\begin{array}{l}\text { Savings } \\
\text { Savings }\end{array}$ & $\begin{array}{c}37,000 \\
5,000\end{array}$ & $\begin{array}{c}0.3 \\
0.04\end{array}$ \\
\hline U.S. & Permanent Wyoming Mineral Trust Fund & 1974 & Mineral revenues & Savings & 4,000 & 0.03 \\
\hline Australia & $\begin{array}{l}\text { Future Fund } \\
\text { Brunei Investment Authority General Reserve }\end{array}$ & 2006 & Fiscal surpluses & Savings & 53,000 & 5.8 \\
\hline Brunei & Fund & 1983 & Oil revenues & Savings & 35,000 & 282.6 \\
\hline $\begin{array}{l}\text { Ireland } \\
\text { New }\end{array}$ & National Pension Reserve Fund & 2001 & Fiscal surpluses & Savings & 31,000 & 12.0 \\
\hline $\begin{array}{l}\text { Zealand } \\
\text { Total }\end{array}$ & Superannuation Fund & 2001 & Fiscal surpluses & Savings & $\begin{array}{c}10,000 \\
2,538,000\end{array}$ & 7.8 \\
\hline
\end{tabular}

Sources: Das (2007), Kern (2007), Truman (2008a, b), Watson Wyatt (2007), Ireland National Pension Reserve (2006), and World Bank (2008). 
Table 3. Reported Asset Allocation and Return for Four Sovereign Wealth Funds

\section{Fund Name}

Government Pension Fund - Global (GPF-G)

New Zealand Superannuation Fund (NZSF)

National Pension Reserve Fund

(NPRF)

Future Fund

\section{Country} Domestic Fixed
Income

Norway

New Zealand

Domestic
Equities

\section{$\mathbf{R e}$

$\mathbf{R e}$

Reported Asset Allocation (\%)
Foreign Fixed Foreign

$\begin{array}{lll}\text { Foreign Fixed } & \text { Foreign } & \text { Other } \\ \text { Income } & \text { Equities } & \text { Investments }\end{array}$

Return

(\%)

Income

59.4

40.6

52.6

0

76

Ireland

Australia
7.3

17.3

0

3.5

12.6
0

3.9

\begin{tabular}{cc}
0 & 7.9 \\
22.8 & 14.6 \\
11.4 & 12.4 \\
18.6 & 7.39 \\
\hline
\end{tabular}

Sources: Australia Future Fund (2008), Norges Bank Investment Management (2006), New Zealand Superannuation Fund (2008), and Ireland National Pension Reserve Fund Commission (2006).

\section{Notes:}

1. In Norway, the GPF-G invests only in global markets. The other wealth fund of the Norwegian government GPF-Norway invests only in local markets. The table reports the nominal return from the whole portfolio in 2006. The portfolio real return (adjusted for inflation) in 2006 was $5.65 \%$. Nominal returns from equities and fixed income instruments in 2006 were $17.04 \%$ and $1.93 \%$ respectively. The annualized nominal return from the portfolio between 1997 and 2006 was $6.49 \%$. The actual asset allocation refers to the situation at the end of 2006.

2. In New Zealand, the NZSF annual reports do not separately report the portfolio share of domestic and foreign fixed income securities, and hence, the portfolio share of domestic bonds (both in benchmark and actual assert allocation cases) includes the portfolio share of the foreign bonds. The remainder of the NZSF portfolio is held in other asset classes such as local and global property, commodities, and private markets. The table reports the nominal return (adjusted for fees but not for inflation) between June 2006 and June 2007. The annualized nominal return from the whole portfolio was $14.81 \%$ between 2003 and 2007. The actual asset allocation refers to end June 2006.

3. In Ireland, the NPRF does not hold Irish government bonds. The portfolio is heavy in alternative asset classes such as property and commodity investments. Foreign bonds consist of only Eurozone bonds and Eurozone equities (including Irish equities); the latter total about 45\% of the portfolio. Since Ireland is a member of the European Union, one might consider Eurozone bonds and equities as domestic for Ireland. The table presents the 2006 nominal rate of return; annualized it was 6.5\%. The asset allocation refers to end 2006.

4. Australia's Future Fund investment program started in June 2007; the benchmark portfolio has not yet been declared and to date the majority of the portfolio has been kept in cash (the table reports the portfolio share of the cash in the cell of domestic fixed income securities) and Telstra shares (this is an Australian telecommunication company). The portfolio share of Telstra Corporation, which is $18.6 \%$, is not reported in the table. The nominal return from the portfolio from June 2006 to June 2007 is reported in the table. The real return (the nominal return after the price inflation adjustment) is 5.29 in the same period. Actual asset allocation is as of June 2007. 
Table 4. Publicly-Managed Pension Asset Pools by Size

\begin{tabular}{|c|c|c|c|c|c|}
\hline Rank & Fund Name & Country & $\begin{array}{l}\text { Inception } \\
\text { year }\end{array}$ & $\begin{array}{c}\text { Assets } \\
\text { (US\$M' 2006) }\end{array}$ & $\begin{array}{l}\text { Assets as } \\
\% \text { of GDP }\end{array}$ \\
\hline 1 & Social Security Trust Fund & U.S. & 1940 & $2,048,112$ & 15.5 \\
\hline 2 & Government Pension Investment & Japan & 2001 & 935,569 & 21.6 \\
\hline 3 & National Pension Fund & $\begin{array}{l}\text { Korea } \\
\text { South }\end{array}$ & 1988 & 190,842 & 21.5 \\
\hline 4 & GEPF & Africa & n.d. & 177,559 & 69.6 \\
\hline 5 & $\begin{array}{l}\text { Postal Savings Fund } \\
\text { National Pension Funds (AP1, AP2, AP3, }\end{array}$ & Taiwan & n.d. & 128,194 & 18.8 \\
\hline 6 & $\begin{array}{l}\text { AP4, AP6) } \\
\text { National Social Security Fund and Social }\end{array}$ & Sweden & 2000 & 117,468 & 30.5 \\
\hline 7 & Insurance Funds & China & 2001/1951 & 104,350 & 3.9 \\
\hline 8 & Canada Pension Plan & Canada & 1997 & 86,392 & 6.9 \\
\hline 9 & Employees Provident Fund & Malaysia & 1991 & 82,256 & 55.2 \\
\hline 10 & Central Provident Fund & Singapore & 1955 & 70,468 & 53.3 \\
\hline 11 & Fondo de Reserva de la Seguridad Social & Spain & 1997 & 44,875 & 3.7 \\
\hline 12 & Public Institute/Social Security & Kuwait & 1977 & 40,482 & 50.1 \\
\hline 13 & Fond de Reserve des Retraites & France & 2000 & 39,140 & 1.8 \\
\hline 14 & Employees Provident Fund & India & 1952 & 31,581 & 3.5 \\
\hline 15 & The State Pension Fund & Finland & 1990 & 12,929 & 6.2 \\
\hline 16 & Social Security Fund & $\begin{array}{l}\text { Thailand } \\
\text { Saudi }\end{array}$ & 1990 & 9,074 & 4.4 \\
\hline 17 & General Organization for Social Insurance & Arabia & 1973 & 8,622 & 2.8 \\
\hline 18 & Social Security Financial Stabilization Fund & Portugal & 1989 & 8,330 & 4.3 \\
\hline 19 & IMSS Reserve & Mexico & n.d. & 7,392 & 0.9 \\
\hline 20 & Social Security Corporation & Jordan & 1980 & 6,023 & 42.5 \\
\hline 21 & Employees' Old-Age Benefits & Pakistan & 1976 & 1,822 & 1.4 \\
\hline 22 & Demographic Reserve Fund & Poland & n.d. & 1,760 & 0.5 \\
\hline 23 & Social Security Fund & Denmark & 1964 & 659 & 0.2 \\
\hline Total & & & & $4,153,899$ & \\
\hline
\end{tabular}

Sources: OECD (2007), Canada Pension Plan Board (2008), Watson Wyatt Worldwide (2006), World Bank (2008), India Employees’ Provident Fund Organization (2008), Singapore Central Provident Fund (2008), Malaysia Employees’ Provident Fund (2008), and Kuwait International Social Security Review (1998).

Note: n.d. = no date 
Table 5. Reported Asset Allocation and Return for Four Publicly-Managed Pension Funds

\begin{tabular}{|c|c|c|c|c|c|c|c|}
\hline \multirow[t]{2}{*}{ Fund Name } & \multirow[t]{2}{*}{ Country } & \multicolumn{5}{|c|}{ Asset Allocation in the Actual Portfolio (\%) } & \multirow[t]{2}{*}{ Return (\%) } \\
\hline & & $\begin{array}{l}\text { Domestic } \\
\text { Fixed } \\
\text { Income }\end{array}$ & $\begin{array}{l}\text { Domestic } \\
\text { Equities }\end{array}$ & $\begin{array}{l}\text { Foreign } \\
\text { Fixed } \\
\text { Income }\end{array}$ & $\begin{array}{l}\text { Foreign } \\
\text { Equities }\end{array}$ & $\begin{array}{l}\text { Other } \\
\text { Investments }\end{array}$ & \\
\hline $\begin{array}{l}\text { Canada Pension Plan Investment Board } \\
\text { (CPPIB) }\end{array}$ & Canada & 24.6 & 25.2 & 0 & 40 & 0 & 12.9 \\
\hline First National Pension Fund (AP1) & Sweden & 10.6 & 13 & 21 & 44.4 & 11 & 9.8 \\
\hline National Pension Fund (NPF) & Korea & 79.3 & 12.1 & 7.3 & 0.4 & 0.9 & 5.39 \\
\hline Government Pension Investment Fund (GPIF) & Japan & 48.4 & 26.3 & 10.4 & 14.9 & 0 & 14.3 \\
\hline
\end{tabular}

Sources: Canada Pension Plan Investment Board (2008); Sweden First AP Fund (2008); Korea National Pension Fund (2008); Japan Government Pension Investment Fund (2008).

\section{Notes:}

1. For Canada, the table shows the nominal rate of return at the end of fiscal 2007 . The annualized nominal rate of return between 2004 and 2007 was $13.6 \%$. The actual asset allocation refers to the situation in 2007.

2. For Sweden, the table shows nominal returns in 2006. The annualized nominal return between 2001 and 2006 was $5.3 \%$. The actual asset allocation refers to 2006. The asset holdings of the other AP funds (AP2, AP3, and AP4) are pretty much same as those of AP1. Fund AP6 is very small and invests only small and medium Swedish companies; it is excluded from the table.

3. For Korea, the benchmark portfolio was not available; the table shows nominal returns in 2005 . The annualized nominal return between 2003 and 2005 was 7.27. The actual asset allocation refers to 2005.

4. For Japan, the table indicates nominal returns in 2005. The annualized nominal return between 2001 and 2005 was 4.1 . Actual asset allocation refers to 2007. 
Table 6. International Guidelines for Public Pension Fund Management

\section{Panel A: World Bank Checklist}

\section{GOVERNANCE}

Are the roles of the respective parties in the public pension scheme clear?

Are the terms under which the managing agency and its governing members appointed and terminated well understood?

Are there adequate fit and proper person protections to prevent the agency from being deliberately manipulated by the government or the Board of the agency?

Is the management agency open and transparent about its governance structures?

Is the scheme open to periodic review; do the government and/or the managing agency welcome constructive criticism?

How well does the agency's internal and/or external governance systems compare with those imposed by the regulator of private pensions?

\section{ACCOUNTABILITY}

Does the public have access to adequate information about the governance structures of the public pensions scheme and its managing agency, either through explicit laws, annual reports, publications and/or web sites? Is disclosure of potential conflicts of interest of Board members required and imposed?

Is the scheme subject to regular independent audit for both governance and performance?

Are the financial performance and financial state of the scheme revealed publicly on a regular basis based on sound accounting standards?

Is the scheme’s financial performance reported against established benchmarks?

Is the government open about its liabilities under the scheme and subject to independent actuarial reviews?

Are the incentive structures within the scheme transparent to the public, linked to delegated responsibilities and risk based?

\section{INVESTMENT}

Is the investment policy fully documented and publicly available?

Is the stated purpose of the scheme to benefit the members of the scheme and, if not, are there potential conflicts between stated objectives?

Does the policy permit lending to government and/or members and, if so, are there transparent guidelines

identifying the issues involved and governing how such investments will take place?

Is the target rate of return based on a long-term funding ratio objective and is it consistent with this objective?

Does the investment policy identify how it will deal with actual or potential market dominance?

Have all major risks been identified and taken into consideration in forming the investment policy? Has the tolerable level of risk been defined by the Board.

Are the processes involved in delegating the implementation of the investment policy to managers clearly

defined? Are benchmark criteria for hiring and firing managers clear and the information needed by the Board to act on them available?

Are the investment parameters defined in terms of restrictions and prohibitions or in terms of modern portfolio concepts?

\section{Panel B: OECD Checklist}

GOVERNANCE

Identification of responsibilities; Governing body; Expert advice; Custodian; Suitability; Redress; Self-investment.

\section{ACCOUNTABILITY}

Auditor; Actuary; Accountability; Internal controls; Reporting; Disclosure; Rigorous process for investment; Publicly available investment policy; Identification of investors; Procedures for investment policy review; Transparent and market based valuation and accounting.

\section{INVESTMENT}

Retirement income objective and prudential principles; Prudent person standard;

Fiduciary duty; Clear investment objectives (liabilities); Strategic asset allocation; Risk management; Investment options; Portfolio limits; International investment; Regular assessment of limits and controls. 
Table 7. Empirical Estimates of Aggregate GAI Scores

Log assets

Current old-age dependency ratio

Future old-age dependency ratio

MWBI

MGCI

Business sophistication

Regulatory quality

Voice and accountability

Rule of law

Government effectiveness

$R$-squared

$N$ \begin{tabular}{l}
\hline \hline Note:* significant at $10 \%$ level; **significant \\
and for variable definitions see Appendix III.
\end{tabular}

\begin{tabular}{rrrrrrc}
\multicolumn{1}{c}{1} & \multicolumn{1}{c}{2} & \multicolumn{1}{c}{3} & \multicolumn{1}{c}{4} \\
\hline-1.61 & $* *$ & -1.34 & & -1.25 & & $-2.41 * *$ \\
0.96 & $* *$ & 0.78 & $* *$ & 0.77 & $* *$ & \\
& & & & & & 0.16
\end{tabular}

$1.62 *$

$-0.75$

$-0.76$

0.74

2.49

$-0.37$

$-0.54$

$2.92 *$

0.69

3.45

$\begin{array}{rrrr}0.68 & 0.68 & 0.68 & 0.41 \\ 26 & 26 & 26 & 26\end{array}$

Note:* significant at 10\% level; **significant at 5\% level. For data sources see Appendix I and II, 
Figure 1. Relative Size of Global Asset Pools

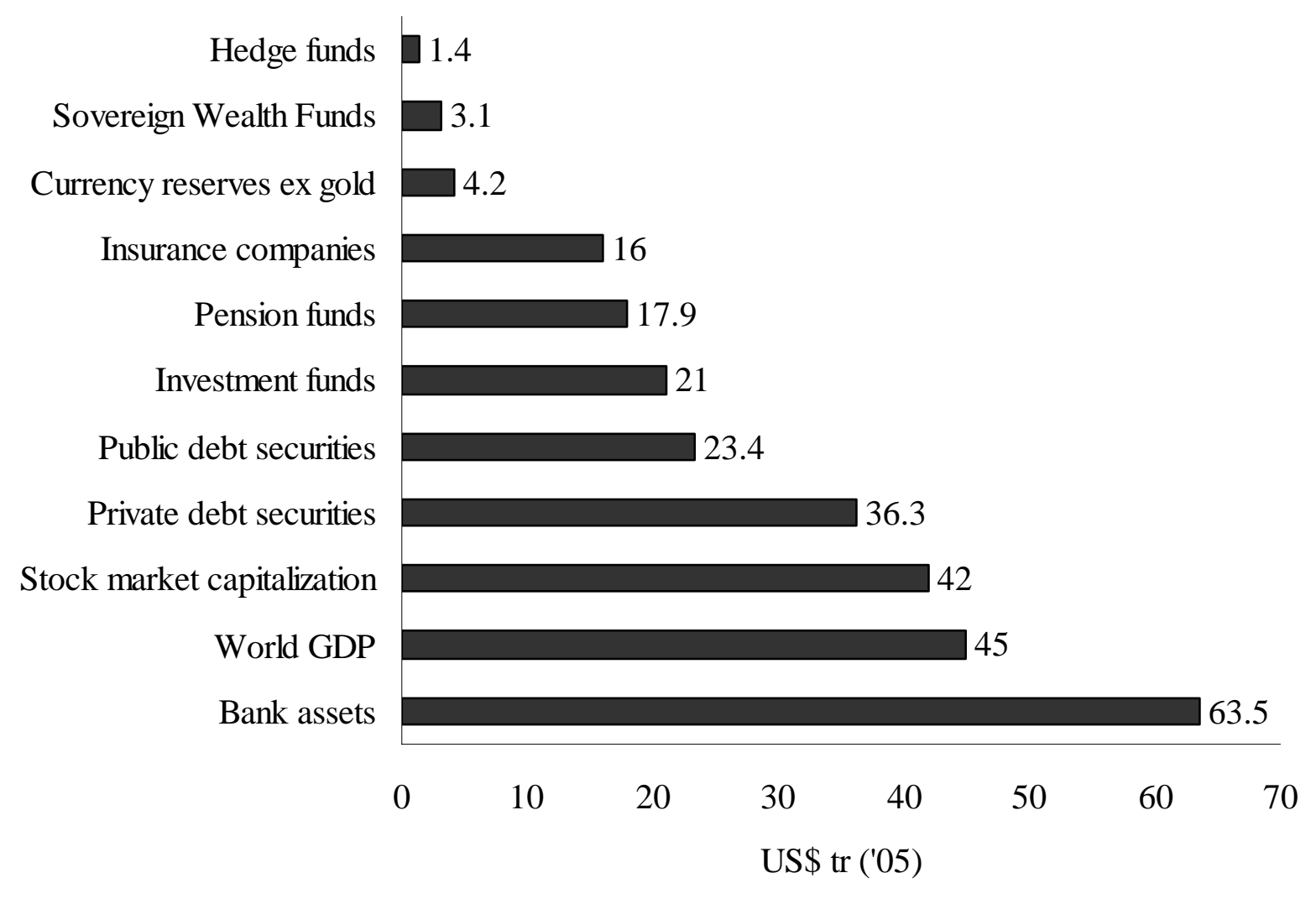

Source: Kern (2007) 


\section{Appendix I: Governance, Accountability, and Investment (GAI) Scores}

\begin{tabular}{|c|c|c|c|c|c|}
\hline Country & Fund & Governance & Accountability & Investment & Total \\
\hline \multicolumn{6}{|l|}{ SWFs } \\
\hline Algeria & Revenue Regulation Fund & 1 & 4 & 4 & 9 \\
\hline Australia & Future Fund & 4 & 11 & 10.5 & 25.5 \\
\hline Azerbaijan & State Oil Fund & 4 & 12 & 8.5 & 24.5 \\
\hline Botswana & Pula Fund & 3 & 7 & 7 & 17 \\
\hline Brunei & Brunei Investment Agency & 1 & 4 & 1 & 6 \\
\hline Canada (Alberta) & Alberta Heritage Savings Trust Fund & 3.5 & 11.5 & 8.5 & 23.5 \\
\hline Chile & Economic and Social Stabilization Fund & 3.5 & 12.5 & 6 & 22 \\
\hline China & Central Huijin Investment Company & 1 & 4 & 4.5 & 9.5 \\
\hline Hong Kong & Exchange Fund & 2 & 11 & 8 & 21 \\
\hline Iran & Oil Stabilization Fund & 1 & 5 & 1.5 & 7.5 \\
\hline Ireland & National Pension Reserve Fund & 5 & 14 & 8.5 & 27.5 \\
\hline Kazakhstan & National Oil Fund & 3.5 & 9 & 7.5 & 20 \\
\hline Kiribati & Revenue Equalization Reserve Fund & 1 & 4 & 3.5 & 8.5 \\
\hline Korea & Korea Investment Corporation & 3 & 5.75 & 7 & 15.75 \\
\hline Kuwait & Kuwait Investment Authority & 4 & 5.25 & 5.5 & 14.75 \\
\hline Malaysia & Khazanah Nasional & 1.5 & 8 & 3 & 12.5 \\
\hline Mexico & Oil Income Stabilization Fund & 2 & 7.5 & 5 & 14.5 \\
\hline New Zealand & Superannuation Fund & 5 & 15 & 10.5 & 30.5 \\
\hline Nigeria & Excess Crude Account & 0 & 5 & 3.5 & 8.5 \\
\hline Norway & Government Pension Fund - Global & 4.5 & 15 & 10 & 29.5 \\
\hline Oman & State General Reserve Fund & 2 & 3.5 & 0.5 & 6 \\
\hline Qatar & Qatar Investment Authority & 1 & 1.25 & 0.75 & 3 \\
\hline Russia & Stabilization Fund & 1 & 8.5 & 6.25 & 15.75 \\
\hline Sao Tome and Principe & National Oil Account & 4 & 6 & 5 & 15 \\
\hline Singapore & Government of Singapore Investment Corporation & 3 & 5.5 & 4 & 12.5 \\
\hline Singapore & Temasek Holdings & 3 & 9.5 & 2.5 & 15 \\
\hline Sudan & Oil Revenue Stabilization Fund & 1.5 & 4 & 0 & 5.5 \\
\hline Timor-Leste & Petroleum Fund & 3 & 14 & 8.5 & 25.5 \\
\hline Trinand\&Tobago & Heritage and Stabilization Fund & 4 & 8 & 4.5 & 16.5 \\
\hline UAE (Abu Dhabi) & Abu Dhabi Investment Authority and Council & 1 & 0.75 & 1.25 & 3 \\
\hline UAE (Abu Dhabi) & Mubadala Development Company & 1 & 1.5 & 2.5 & 5 \\
\hline UAE (Dubai) & Istithmar World & 1 & 2.5 & 1 & 4.5 \\
\hline US (Alaska) & Alaska Permanent Fund & 4 & 15 & 11 & 30 \\
\hline US (New Mexico) & Severance Tax Permanent Fund & 3.5 & 12 & 12 & 27.5 \\
\hline US (Wyoming) & Permanent Mineral Trust Fund & 5 & 12 & 12 & 29 \\
\hline Venezuela & Macro Stabilization Fund & 1 & 4.5 & 2 & 7.5 \\
\hline Venezuela & National Development Fund & 1 & 4.75 & 1 & 6.75 \\
\hline Average & & 2.5 & 7.7 & 5.4 & 15.6 \\
\hline
\end{tabular}

Sources: Truman (2008a, b) and authors' calculations; see Appendix II. 
Appendix II. Criteria for Sovereign Wealth Fund Management Practices

Governance (G)

Are the guidelines for fiscal treatment generally followed without frequent adjustment? (Structure)

Is the SWF separate from the country's international reserves? (Structure)

Does the SWF ethical guidelines that it follows? (Governance)

Is the audit independent? (Transparency and Accountability)

Are decisions on specific investments made by the managers? (Governance)

Accountability (A)

Is the SWF's objective clearly communicated? (Structure)

Is the source of the SWF's funding clearly specified? (Structure)

Is nature of the subsequent use of the principal and earnings in the fund clearly stated? (Structure)

Does the SWF have in place and publicly available guidelines for corporate responsibility that it follows? (Governance)

Does the SWF provide at least an report on its activities and results? (Transparency and Accountability)

Does the SWF provide quarterly report on its activities? (Transparency and Accountability)

Do regular reports on the investments by the SWF include the size of the fund? (Transparency and Accountability)

Do regular reports on the investments by the SWF include information on the return it earns? (Transparency and Accountability)

Do regular reports on the investments by the SWF include information on the types of investments? (Transparency and Accountability)

Do regular reports on the investments by the SWF include information on the geographic location of investments? (Transparency and Accountability)

Do regular reports on the investments by the SWF include information on the specific investments? (Transparency and Accountability)

Do regular reports on the investments by the SWF include information on the currency composition of investments? (Transparency and Accountability)

Are the holders of investment mandates identified? (Transparency and Accountability)

Is the SWF subjected to a regular audit? (Transparency and Accountability)

Is the audit published? (Transparency and Accountability)

Investment (I)

Is the overall investment strategy clearly communicated? (Structure)

Is the procedure for the changing the structure clear? (Structure)

Is the role of the government in the setting the investment strategy of the SWF clearly established? (Governance)

Is the role of the manager in executing the investment strategy clearly established? (Governance)

Does the SWF indicate the nature and speed of adjustment in its portfolio? (Behaviour)

Does the strategy use benchmarks? (Transparency and Accountability)

Does the strategy limit investments based on credit ratings? (Transparency and Accountability)

Does the SWF have limits on the size of its stakes? (Behaviour)

Does the SWF not take controlling stakes? (Behaviour)

Does the SWF have a policy on the use of leverage? (Behaviour)

Does the SWF have a policy on the use of derivatives? (Behaviour)

Are derivatives used primarily for hedging? 


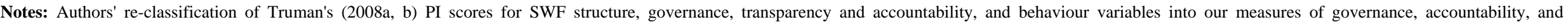
transparency. The PI scoreboard question is shown in italics. 
Appendix III. Variable Definitions and Sources for Empirical Analysis of Public Fund Management Practices

\begin{tabular}{|c|c|c|c|c|c|c|}
\hline Variable & Definition & Mean & $\frac{\text { Standard }}{\text { Deviation }}$ & $\underline{\operatorname{Min}}$ & Max & Data source \\
\hline Total & Sum of Governance, Accountability, and Investment scores. & 16.80 & 8.49 & 2.25 & 29.94 & $\begin{array}{l}\text { Truman }(2008 a) \& \\
\text { authors' calculations }\end{array}$ \\
\hline Governance & Measures how well a SWF is governed. & 2.64 & 1.37 & 0.00 & 5.00 & $\begin{array}{l}\text { Truman (2008a) \& } \\
\text { authors' calculations }\end{array}$ \\
\hline Accountability & Measures degree of accountability. & 8.13 & 4.38 & 0.20 & 15.00 & $\begin{array}{l}\text { Truman (2008a) \& } \\
\text { authors' calculations }\end{array}$ \\
\hline Investment & Measures how well the SWF investment activities are structured. & 6.03 & 3.25 & 0.50 & 11.20 & $\begin{array}{l}\text { Truman }(2008 a) \& \\
\text { authors' calculations }\end{array}$ \\
\hline Log Asset & Log of assets held by the sovereign wealth fund. & 3.46 & 1.67 & 0.69 & 6.80 & $\begin{array}{l}\text { Truman (2008a) \& } \\
\text { authors' calculations }\end{array}$ \\
\hline $\begin{array}{l}\text { Current old-age } \\
\text { dependency ratio }\end{array}$ & Ratio of population age $65+$ to population age $15-64$ (in 2005). & 10.96 & 6.10 & 1.00 & 22.00 & UN (2008) \\
\hline $\begin{array}{l}\text { Future old-age } \\
\text { dependency ratio } \\
\text { in } 2040 \text {. }\end{array}$ & Ratio of population age $65+$ to population age $15-64$ (in 2040). & 28.50 & 13.88 & 7.00 & 59.00 & UN (2008) \\
\hline $\begin{array}{l}\text { Modified World } \\
\text { Bank } \\
\text { Governance } \\
\text { Index (WBGI) }\end{array}$ & $\begin{array}{l}\text { Measure of good national governance practices with indicators of voice and } \\
\text { accountability, political stability, government effectiveness, regulatory quality, rule of } \\
\text { law, and control of corruption. Principal components analysis is used to generate data- } \\
\text { weighted aggregate score of national governance practices. }\end{array}$ & -0.22 & 2.31 & -3.99 & 3.02 & $\begin{array}{l}\text { Kaufmann et al.. } \\
\text { (2007) \& authors' } \\
\text { calculations. }\end{array}$ \\
\hline $\begin{array}{l}\text { Modified Global } \\
\text { Competitiveness } \\
\text { Index (GCI) }\end{array}$ & $\begin{array}{l}\text { Measure of economic competitiveness: index of national competitiveness derived by } \\
\text { measures of quality of institutions, infrastructure, macroeconomy, higher education/ } \\
\text { training, goods market efficiency, financial market sophistication, technological } \\
\text { readiness, market size, business sophistication, and innovation. Principal components } \\
\text { analysis is used to generate data-weighted aggregate measure of competitiveness. }\end{array}$ & -0.33 & 2.91 & -6.49 & 4.08 & $\begin{array}{l}\text { Martin et al.. (2007) } \\
\text { \& authors' } \\
\text { calculations. }\end{array}$ \\
\hline $\begin{array}{l}\text { Business } \\
\text { sophistication }\end{array}$ & $\begin{array}{l}\text { Measures quality of a country's overall business networks and firms' operations and } \\
\text { strategies; higher scores indicate more business sophistication. }\end{array}$ & 4.41 & 0.75 & 2.78 & 5.60 & Martin et al. (2007). \\
\hline $\begin{array}{l}\text { Regulatory } \\
\text { quality }\end{array}$ & $\begin{array}{l}\text { Measures government's ability to generate/implement policies that benefit the private } \\
\text { sector. }\end{array}$ & 0.49 & 1.06 & -1.47 & 1.95 & $\begin{array}{l}\text { Kaufmann et al. } \\
\text { (2007) }\end{array}$ \\
\hline $\begin{array}{l}\text { Voice and } \\
\text { accountability }\end{array}$ & $\begin{array}{l}\text { Measures citizenry's participation in selecting government; freedom of expression; } \\
\text { freedom of association; and free media }\end{array}$ & 0.07 & 0.99 & -1.66 & 1.64 & $\begin{array}{l}\text { Kaufmann et al. } \\
\text { (2007). }\end{array}$ \\
\hline Rule of law & Measures quality of judicial system. & 0.47 & 1.14 & -1.39 & 2.02 & $\begin{array}{l}\text { Kaufmann et al. } \\
\text { (2007). }\end{array}$ \\
\hline $\begin{array}{l}\text { Government } \\
\text { effectiveness }\end{array}$ & $\begin{array}{l}\text { Measures quality of public and civil services; independence of public and civil services } \\
\text { from political pressures; quality of policy formulation and implementation; and } \\
\text { government credibility. }\end{array}$ & 0.60 & 1.05 & -0.96 & 2.20 & $\begin{array}{l}\text { Kaufmann et al. } \\
\text { (2007). }\end{array}$ \\
\hline
\end{tabular}

Source: As indicated and authors' calculations; see text. 
Appendix IV. Correlation Matrix for Empirical Variables

\begin{tabular}{|c|c|c|c|c|c|c|c|c|c|c|c|c|c|}
\hline & 1 & 2 & 3 & 4 & 5 & 6 & 7 & 8 & 9 & 10 & 11 & 12 & 13 \\
\hline 1. GAI & 1.00 & & & & & & & & & & & & \\
\hline 2. $G$ & 0.81 & 1.00 & & & & & & & & & & & \\
\hline 3. A & 0.97 & 0.73 & 1.00 & & & & & & & & & & \\
\hline 4. I & 0.96 & 0.73 & 0.89 & 1.00 & & & & & & & & & \\
\hline 5. Log Fund Assets & -0.22 & -0.19 & -0.26 & -0.14 & 1.00 & & & & & & & & \\
\hline 6. Current old-age dependency ratio & 0.72 & 0.46 & 0.70 & 0.76 & 0.11 & 1.00 & & & & & & & \\
\hline 7. Future old-age dependency ratio & 0.34 & 0.33 & 0.29 & 0.36 & 0.36 & 0.70 & 1.00 & & & & & & \\
\hline 8. MWBI & 0.47 & 0.53 & 0.43 & 0.42 & 0.31 & 0.50 & 0.55 & 1.00 & & & & & \\
\hline 9. MGCI & 0.38 & 0.38 & 0.34 & 0.38 & 0.46 & 0.59 & 0.74 & 0.85 & 1.00 & & & & \\
\hline 10. Business sophistication & 0.31 & 0.34 & 0.28 & 0.29 & 0.43 & 0.47 & 0.67 & 0.76 & 0.96 & 1.00 & & & \\
\hline 11. Regulatory quality & 0.41 & 0.46 & 0.41 & 0.34 & 0.29 & 0.44 & 0.48 & 0.93 & 0.78 & 0.71 & 1.00 & & \\
\hline 12. Voice and accountability & 0.69 & 0.65 & 0.64 & 0.65 & -0.07 & 0.63 & 0.45 & 0.81 & 0.64 & 0.56 & 0.68 & 1.00 & \\
\hline 13. Rule of law & 0.42 & 0.50 & 0.37 & 0.39 & 0.37 & 0.46 & 0.56 & 0.98 & 0.89 & 0.81 & 0.88 & 0.76 & 1.00 \\
\hline 14. Government effectiveness & 0.46 & 0.45 & 0.45 & 0.40 & 0.34 & 0.52 & 0.54 & 0.97 & 0.83 & 0.73 & 0.95 & 0.75 & 0.93 \\
\hline
\end{tabular}

Source: Authors' calculations; see text and Appendix III. 